\title{
Synaptic Inputs to ON Parasol Ganglion Cells in the Primate Retina
}

\author{
Roy Jacoby, Donna Stafford, Nobuo Kouyama, and David Marshak \\ Department of Neurobiology and Anatomy, The University of Texas Medical School, Houston, Texas 77225
}

In primates, the retinal ganglion cells that project to the magnocellular layers of the lateral geniculate nucleus have distinctive responses to light, and one of these has been identified morphologically as the parasol ganglion cell. To investigate their synaptic connections, we injected parasol cells with Neurobiotin in lightly fixed baboon retinas. The five $\mathrm{ON}$-center cells we analyzed by electron microscopy received $\sim 20 \%$ of their input from bipolar cells. The major synaptic input to parasol cells was from amacrine cells via conventional synapses and, in this respect, they resembled $\alpha$ ganglion cells of the cat retina. We also found the gap junctions between amacrine cells and parasol ganglion cells that had been predicted from tracercoupling experiments. To identify the presynaptic amacrine cells, ON-center parasol cells were injected with Neurobiotin and Lucifer yellow in living macaque retinas, which were then fixed and labeled by immunofluorescence. Two kinds of amacrine cells were filled with Neurobiotin via gap junctions: a large, polyaxonal cell containing cholecystokinin and a smaller one without cholecystokinin. There were also appositions between cholecystokinin-containing amacrine cell processes and parasol cell dendrites. Cholinergic amacrine cell processes often followed parasol cell dendrites and made extensive contacts. In other mammals, the light responses of polyaxonal amacrine cells like these and cholinergic amacrine cells have been recorded, and the effects of acetylcholine and cholecystokinin on ganglion cells are known. Using this information, we developed a model of parasol cells that accounts for some properties of their light responses.

Key words: monkey; amacrine cell; bipolar cell; gap junction; cholecystokinin; acetylcholine
Parasol ganglion cells have been recognized as a distinct morphological type in the primate retina for more than 100 years (for review, see Rodieck et al., 1985), and they make up $\sim 10 \%$ of the retinal ganglion cells (Perry et al., 1984). They are also called M cells because they project to the magnocellular layers of the lateral geniculate nucleus (Bunt et al., 1975; Leventhal et al., 1981; Casagrande and DeBruyn, 1982; Itoh et al., 1982; Perry et al., 1984; Perry and Silveira, 1988; Naito, 1989). The magnocellular cells, in turn, provide a major input to the primary visual cortex that ultimately contributes to many aspects of visual perception, but is particularly important for the perception of motion (for review, see Merigan and Maunsell, 1993). The ON-parasol ganglion cells respond with an increase in firing rate at the onset of light in the center of the receptive field and a decrease to light in the surround. OFF cells have the opposite responses. ON-parasol cells ramify in the fourth stratum of the inner plexiform layer (IPL), and OFF parasol cells ramify in the second stratum (Dacey and Lee, 1994).

\footnotetext{
Received Aug. 5, 1996; revised Sept. 23, 1996; accepted Sept. 27, 1996.

This work was supported by Grants R01 EY06472, P30 EY10608, T32 EY07024, and F32 EY06471 from the National Eye Institute, F31 MH10957 from the National Institute of Mental Health, PD 92040 from Fight for Sight, Inc., and 011618027 from the Texas Higher Education Coordinating Board. We thank Mrs. Lillemor Krosby for excellent technical assistance, Dr. Alice Chuang for assistance with the statistical analysis, Dr. Charles Sims for drawing Figure 10, and Mrs. Rama Grenda for drawing Figure 18. We also thank Dr. David Hall, Dr. Garrett Kenyon, Dr. Helga Kolb, and Dr. Stephen Massey for helpful comments on this manuscript. We are also grateful to Dr. James Willerson, Dr. Roger Price, and Ms. Janice McNatt for providing the tissue used in these experiments.

Correspondence should be addressed to David W. Marshak, Department of Neurobiology and Anatomy, The University of Texas Medical School, Box 20708, Houston, TX 77225.

Dr. Stafford's present address: Department of Biological Structure, University of Washington, Seattle, WA 98195.

Dr. Kouyama's present address: Department of Physiology, Tokyo Women's Medical College, Tokyo 162, Japan.

Copyright (C) 1996 Society for Neuroscience $0270-6474 / 96 / 168041-16 \$ 05.00 / 0$
}

Parasol cells are more sensitive to luminance contrast than the color-opponent ganglion cells that project to the parvocellular layers, and they respond more transiently to light stimuli at all levels of adaptation (for review, see Kaplan et al., 1990). One possible explanation for these differences is that the local circuit neurons presynaptic to parasol cells have these characteristics, but very little was known about them. The first step in identifying these presynaptic neurons was to determine the relative contributions of amacrine cells and bipolar cells in an electron microscopic study of Neurobiotin-injected ON-parasol cells from the peripheral retina. Approximately $80 \%$ of the input to parasol cells was from at least two types of amacrine cells. Amacrine cells are labeled when parasol cells are injected with Neurobiotin (Dacey and Brace, 1992; Ghosh et al., 1996), but the mechanism of this tracer coupling was uncertain. We also found that parasol cells make gap junctions with proximal dendrites of amacrine cells.

We then did light microscopic double-labeling experiments to study the interactions of injected parasol ganglion cells with two types of amacrine cells that costratified with parasol cells and were known to make synapses onto ganglion cells (Mariani and Hersh, 1988; Marshak et al., 1990). The first was a large cell immunoreactive for the glycine-extended cholecystokinin precursor (G6-gly-IR) that resembles one of the amacrine cells tracer-coupled to parasol cells. We confirmed this by double labeling and found numerous contacts between G6-gly-IR amacrine cells and parasol cells. We also found that choline acetyltransferase-immunoreactive (ChAT-IR) displaced amacrine cells contacted parasol ganglion cells. Based on results in other species, we predict that acetylcholine contributes to the transient excitation at the beginning of parasol cell light responses, that cholecystokinin contributes to the inhibition that follows and that gap junctions from amacrine cells enhance both components. 


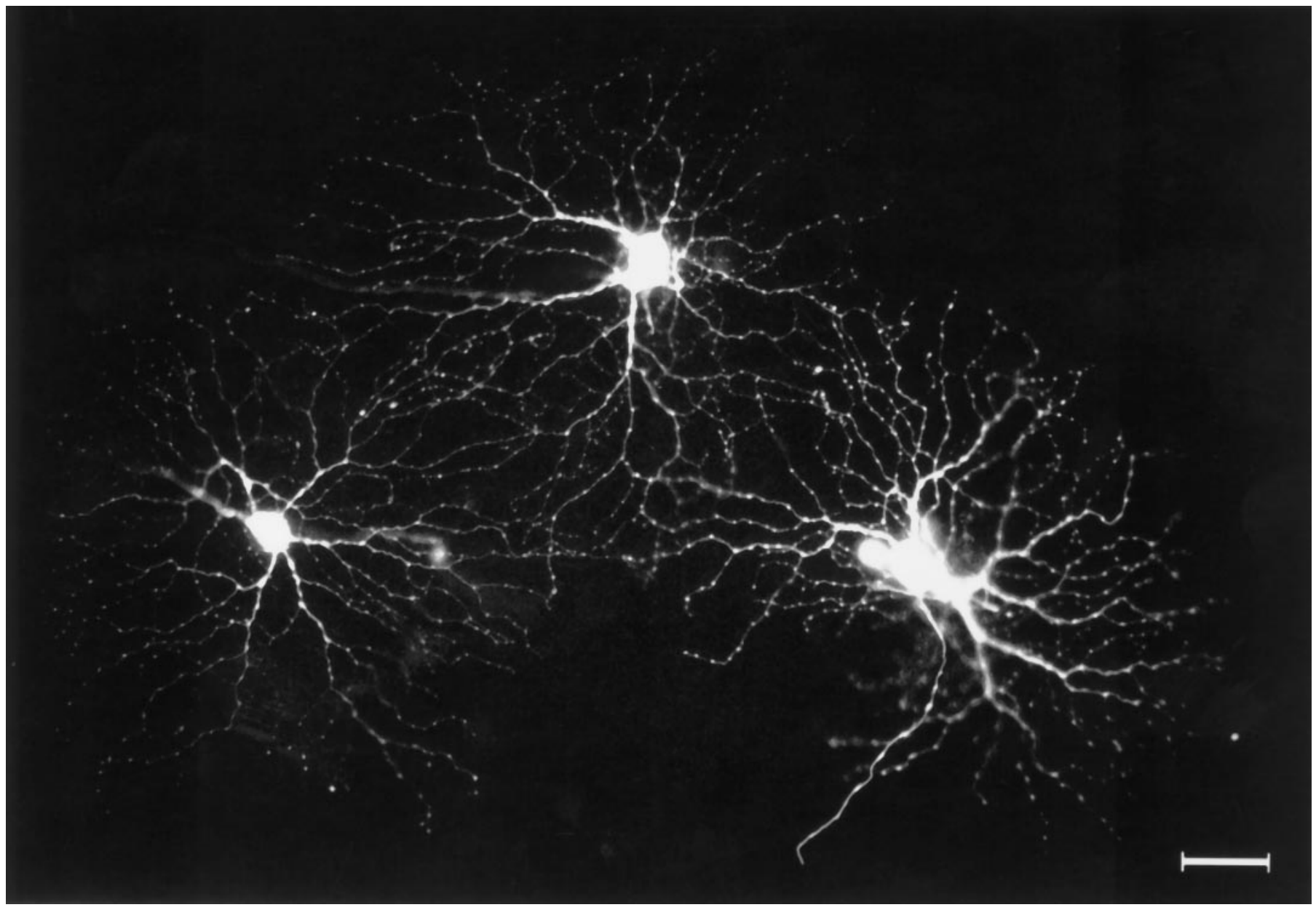

Figure 1. Fluorescence micrograph of three ON-parasol cells injected with Lucifer yellow in a living macaque retina. Note that virtually all of the dendrites are in a single plane of focus, which indicates that they are in the same narrow stratum of the IPL. Preparations like this were used for double-labeling experiments. Scale bar, $50 \mu \mathrm{m}$.

\section{MATERIALS AND METHODS}

Labeling of parasol cells for correlated light and electron microscopy. Eyes were enucleated within 20 min postmortem from baboons (Papio cynocephalus anubis) that had been overdosed with sodium pentobarbital $(50-100 \mathrm{mg} / \mathrm{kg}$, i.v. ) by other investigators at the conclusion of experiments that did not involve the eyes. The baboon eyes were hemisected and fixed by immersion for $30 \mathrm{~min}$ at $20^{\circ} \mathrm{C}$ in $0.1 \%$ glutaraldehyde and $2 \%$ paraformaldehyde in $0.1 \mathrm{M}$ sodium phosphate, $\mathrm{pH} 7.4$, rinsed, and stored in the same buffer $(\mathrm{PB})$ at $4^{\circ} \mathrm{C}$. The retinas were divided into three regions: central, within $5 \mathrm{~mm}$ of the fovea; mid-peripheral, $5-10 \mathrm{~mm}$ from the fovea; and far-peripheral, further than $10 \mathrm{~mm}$ from the fovea. Only mid-peripheral and far-peripheral pieces were used for these experiments. Using fine forceps, the vitreous humor was removed and the retina was dissected free of the retinal pigment epithelium.

The procedure for intracellular injection of Neurobiotin into parasol cells under visual control was a modification of the technique first described by Tauchi and Masland (1984) and similar to that described by Dacey and Brace (1992) except that the tissue was fixed and PB was substituted for Ames medium. The retinas were treated with acridine orange (4 min, $10 \mu \mathrm{M}$ ) and mounted on the stage of a Zeiss Standard upright, fixed-stage microscope with a $30 \times$ long-working-distance objective. Microelectrodes made from thin-walled borosilicate glass $(50-100$ $\mathrm{M} \Omega$ ) were filled with $2.5 \%$ Lucifer yellow (Molecular Probes, Eugene, OR) and 5\% Neurobiotin (Vector Laboratories, Burlingame, CA) in 20 mM 3-[N-morpholino]propanesulfonic acid (MOPS; Sigma, St. Louis, $\mathrm{MO}), \mathrm{pH}$ 7.6. Retinal ganglion cells with the largest perikarya were injected with Lucifer yellow for 1-2 min with $400 \mathrm{msec}$ square-wave pulses at $2 \mathrm{~Hz}$ with $5-10 \mathrm{nA}$ of negative current until the cell was confirmed to be a parasol cell, and then they were filled with Neurobiotin using positive current of the same amplitude, frequency, and duration for
3-6 min, depending on the electrode resistance. The retinas were postfixed overnight with $2 \%$ glutaraldehyde and $4 \%$ paraformaldehyde in 0.1 $\mathrm{M}$ PB, $\mathrm{pH}$ 7.4, and rinsed in PBS after this and all other steps unless noted otherwise. The retinas were processed to visualize the parasol cells, as described previously (Marshak et al., 1990). The tissue was treated with $1 \%$ sodium borohydride in PBS (60 min) and an ascending and descending series of graded ethanol solutions in PBS (10 min each in 10,25 , and $40 \%$; $30 \mathrm{~min}$ in $50 \%$; $10 \mathrm{~min}$ each in 40,25 , and $10 \%$ ). The Neurobiotin was visualized using Vector avidin-biotin-peroxidase (1:100, overnight at $\left.4^{\circ} \mathrm{C}\right)$ and diaminobenzidine $(0.5 \mathrm{mg} / \mathrm{ml})$ with hydrogen peroxide $(0.005 \%$, $60 \mathrm{~min})$. The retinas were then osmicated (1\% in PB, $60 \mathrm{~min})$ and embedded in Epon on glass slides with the ganglion cells upward. The injected cells were identified again, and cells were drawn with a camera lucida or photographed. Areas containing amacrine cells that may have been labeled by tracer coupling were not used. Four cells were cut out and reembedded whole, and one cell was cut with a sliding microtome into $60 \mu \mathrm{m}$ sections, which were mounted on Epon blanks. Approximately 100-nm-thick sections were collected on formvar-coated, single-hole grids and stained with uranyl acetate (2\% in 50\% methanol, $60 \mathrm{~min}$ ). Labeled parasol cell dendrites from all five were first photographed at $2000 \times$ to verify that they branched in the inner half of the inner plexiform layer (IPL). We photographed 100 or more profiles with synaptic specializations from each of 5 cells, and we examined additional sections of these cells to look for gap junctions. The presynaptic cells were typically followed through sets of 5-10 serial sections at $10,000 \times$, and they were identified using established, ultrastructural criteria (Dowling and Boycott, 1966; Koontz and Hendrickson, 1987). Using a goniometer stage to optimize the orientation of the membranes, synapses were photographed at $20,000 \times$ and, in the case of gap junctions, also at $50,000 \times$ or $100,000 \times$. The negatives containing gap junctions were scanned at 2400 dpi using a 


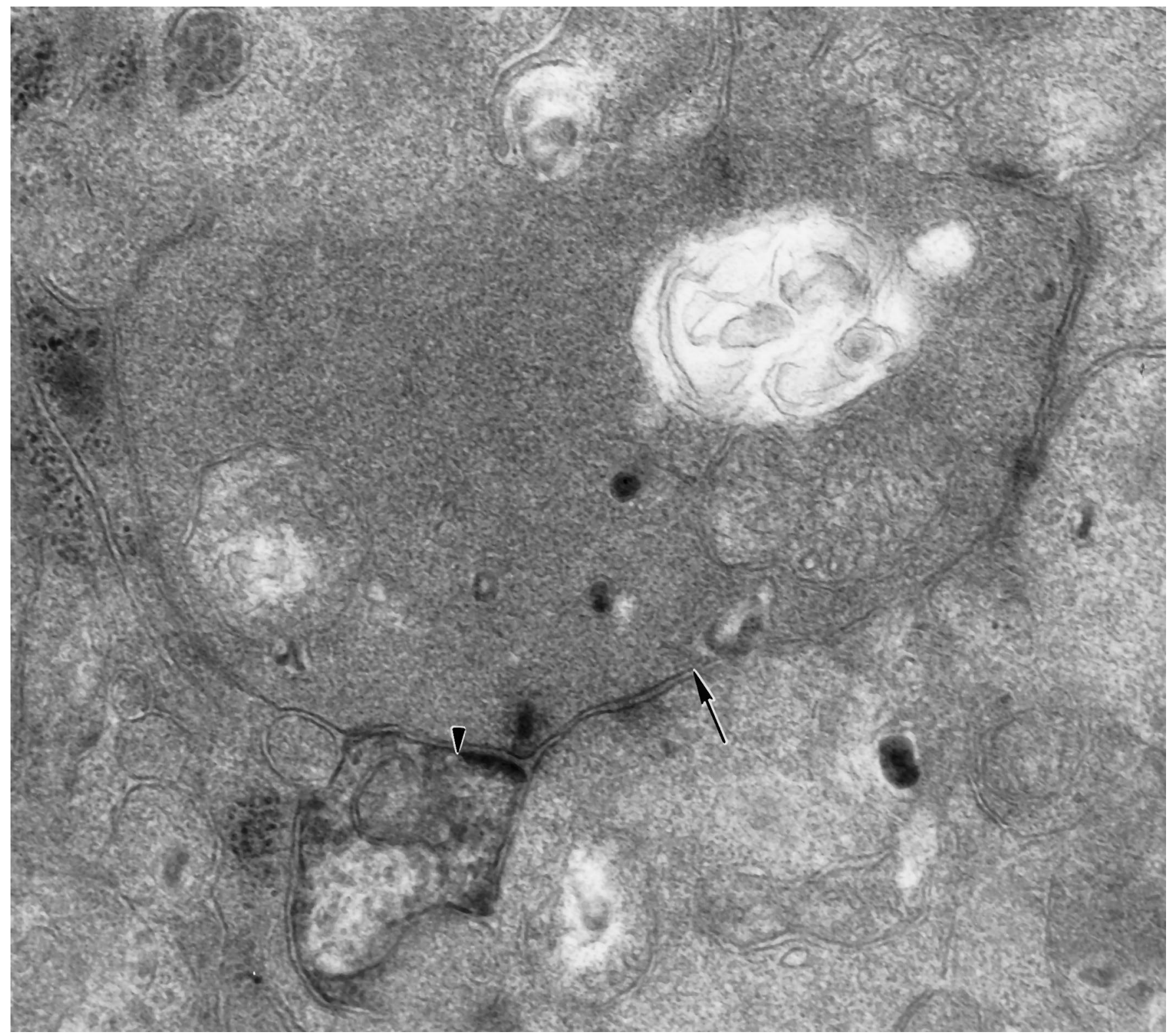

Figure 2. A large bipolar cell axon terminal contacts a labeled parasol ganglion cell dendrite (arrowhead). The amacrine cell that is the other member of the dyad makes a feedback synapse (arrow) onto the bipolar cell axon $(60,000 \times)$.

\section{Table 1. Synaptic inputs to ON-parasol ganglion cells}

\begin{tabular}{llllrl} 
Animal & Cell number & \multicolumn{2}{c}{$\begin{array}{c}\text { Inputs from } \\
\text { bipolar cells }\end{array}$} & \multicolumn{2}{c}{$\begin{array}{c}\text { Inputs from } \\
\text { amacrine cells }\end{array}$} \\
\hline 1 & 1 proximal & 9 & $21 \%$ & 34 & $79 \%$ \\
& distal & 85 & $24 \%$ & 265 & $76 \%$ \\
1 & 2 & 36 & $17 \%$ & 172 & $83 \%$ \\
2 & 3 & 41 & $17 \%$ & 198 & $83 \%$ \\
2 & 4 & 19 & $13 \%$ & 122 & $87 \%$ \\
2 & 5 & 21 & $18 \%$ & 95 & $82 \%$
\end{tabular}

Synaptic connections of 5 ON-parasol ganglion cells from two baboons. Cell 1 was first sectioned with a sliding microtome, and the sections containing the perikaryon and proximal dendrites were compared with those containing only distal dendrites. Amacrine cells provided the major input to both regions. The remaining 4 cells were not sampled systematically. They received $83 \%$ of their input from amacrine cells on average. No significant differences among these 4 cells were observed using a $\chi^{2}$ test $\left(\chi^{2}=1.3, p=0.73\right)$.
UMAX scanner with a transparency adapter. Pixel intensity values were measured in a rectangular area 15 pixels wide and spanning the junctions using Sigmascan Pro (Jandel Scientific, Corte Madera, CA).

Double labeling for confocal laser scanning microscopy. For light microscopic double-labeling experiments, macaque eyes (Macaca mulatta) were enucleated within $10 \mathrm{~min}$ after an overdose of sodium pentobarbital $(50-100 \mathrm{mg} / \mathrm{kg}$, i.v.) and transported to the laboratory inside glass jars packed in ice. They were dissected within 10-15 min of enucleation in oxygenated Ames medium (Sigma) at room temperature. The eyes were hemisected, and the posterior halves were cut into quarters. Using fine forceps, the vitreous and the sclera were removed, and the retina-pigment epithelium-choroid preparation was superfused with oxygenated Ames medium in dim, white light at $20^{\circ} \mathrm{C}$. The protocols for injection of Neurobiotin and Lucifer yellow were the same as described above except that the tissue was alive. The preparations were fixed overnight in $2 \%$ paraformaldehyde in $\mathrm{PB}$, and the retina was isolated. In the first experiments, only Lucifer yellow was injected, and the retinas were chopped into $90 \mu \mathrm{m}$ sections with a Mcllwain Tissue Chopper (The Mickle Laboratory Engineering Co.). The sections were then labeled with 1:1000 rabbit anti-G6-gly (provided by Dr. John DelValle, University of Michi- 


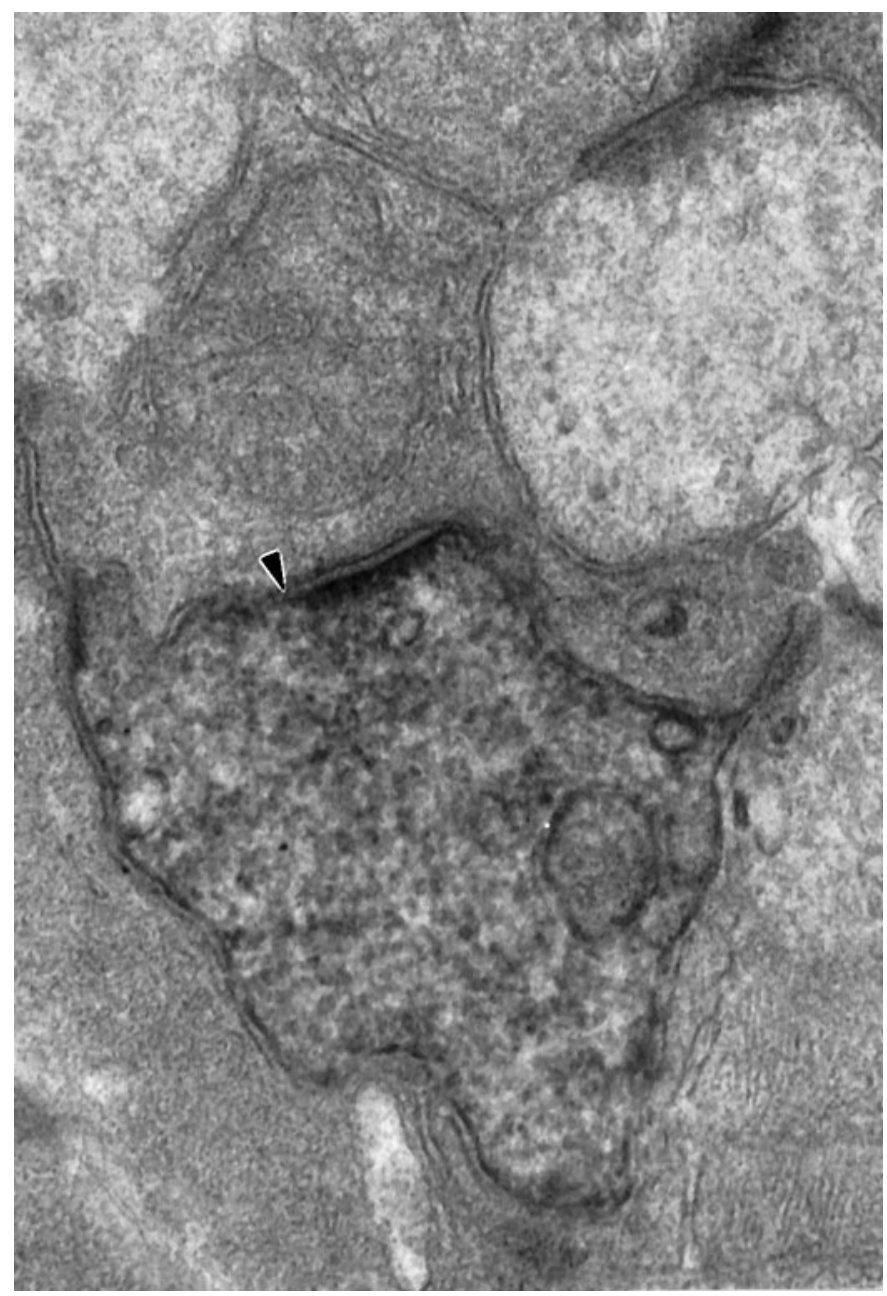

Figure 3. A dark, irregularly shaped amacrine cell process is presynaptic to a parasol ganglion cell dendrite (arrowhead); more electron-lucent amacrine cell processes are found on either side of the presynaptic process $(60,000 \times)$.

gan, Ann Arbor, MI), biotinylated goat anti-rabbit IgG (Vector) at 1:100 for $2 \mathrm{~d}$ and 1:100 Streptavidin-Cy3 (Jackson ImmunoResearch Laboratories, West Grove, PA) for $2 \mathrm{~d}$. In later experiments, the retinas were incubated for 1-2 d in Cy3-conjugated Streptavidin (1:100 in PBS with $0.3 \%$ sodium azide and $0.3 \%$ Triton X-100, (Jackson ImmunoResearch Laboratories, West Grove, PA). The isolated retinas were then labeled with $1: 500$ to $1: 1000$ anti-G6-gly containing $0.3 \%$ Triton $\mathrm{X}-100$ as described previously (Kouyama and Marshak, 1992) or 1:200 affinitypurified anti-choline acetyltransferase (Chemicon, Temecula, CA). The second antibodies were Cy5-conjugated to either goat anti-rabbit IgG or horse anti-goat $\mathrm{IgG}$, both at 1:100 in PBS with $0.3 \%$ sodium azide (Jackson ImmunoResearch Laboratories, West Grove, PA ). The retinas were mounted ganglion cell side upward in glycerol (3 parts) to PBS (1 part) with $0.3 \%$ sodium azide and $0.1 \%$ paraphenylenediamine (Sigma) and examined in a Zeiss confocal laser scanning microscope with a krypton-argon laser. Excitation was at $488 \mathrm{~nm}$ for Lucifer yellow, $568 \mathrm{~nm}$ for Cy3, and $647 \mathrm{~nm}$ for Cy5. The filter blocks were 515-540 for Lucifer yellow, 590-610 for Cy3, and 670-810 for Cy5. The diameters of the perikarya of labeled amacrine cells were determined using Zeiss LSM software.

Photoshop 3.0 (Adobe Systems, Mountain View, CA) was used to process the confocal images for publication and for statistical analysis. Whole-mount preparations contained immunoreactive processes, which were designated green, and injected parasol cells, which were designated red. We superimposed the two images, which were each reconstructed from a stack of 10-15 optical sections, and identified sites of apposition, where the labeled processes were within $0.6 \mu \mathrm{m}$, the $z$-axis resolution. We confirmed that the appositions were not separated by more than $0.6 \mu \mathrm{m}$

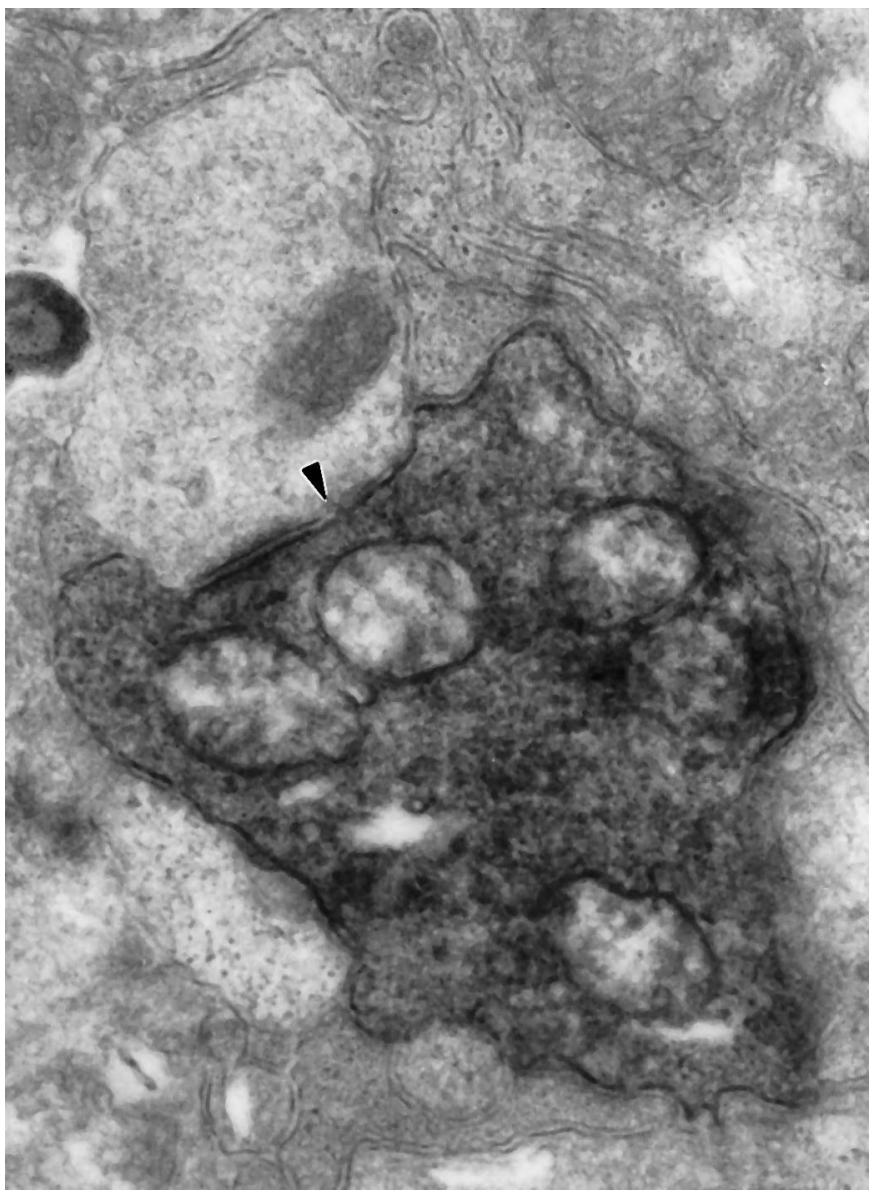

Figure 4. An electron-lucent amacrine cell process is presynaptic to a large, labeled parasol ganglion cell dendrite (arrowhead; 60,000×).

using the individual optical sections. The pixels in these areas appeared yellow, but there was a wide range of yellow values in each image because of variation in the size and intensity of labeled processes. Therefore, yellow was defined for each image by sampling a typical site of apposition between red and green processes of intermediate intensity. All of the similarly colored pixels in each image and its corresponding control images were selected using the "select color range" command in Photoshop. To extend the range of yellow hues that were counted, a tolerance factor of 200 was used when selecting pixels. This value included areas of overlap between parasol cell dendrites and G6-gly-IR processes of intermediate to high intensity, but not lower-level background labeling. The pixels were counted using the "histogram" function. The yellow pixels were also counted in three control images that we created for each analyzed area by rotating the Neurobiotin signal relative to the immunoreactive signal (Vardi et al., 1989; Massey et al., 1996). The Neurobiotin signal was rotated $90^{\circ}, 180^{\circ}$, and $270^{\circ}$, the yellow pixels were counted in each control image, and the three were averaged. The pixel counts from the control and original images were compared using a paired $t$ test.

\section{RESULTS}

\section{Morphology of ON-parasol ganglion cells}

The ganglion cells that were injected in lightly fixed baboon retina were clearly identifiable as parasol cells. Like the parasol cells labeled by intracellular injection in living retinas illustrated in Figure 1 and by other groups previously (Watanabe and Rodieck, 1989; Dacey and Petersen, 1992; Goodchild et al., 1996), their perikarya, axons, and proximal dendrites were large in diameter. Many smaller dendrites were also filled, and in the electron microscope, synapses were observed on processes as narrow as $0.25 \mu \mathrm{m}$ in diameter. Their dendrites branched densely within a 


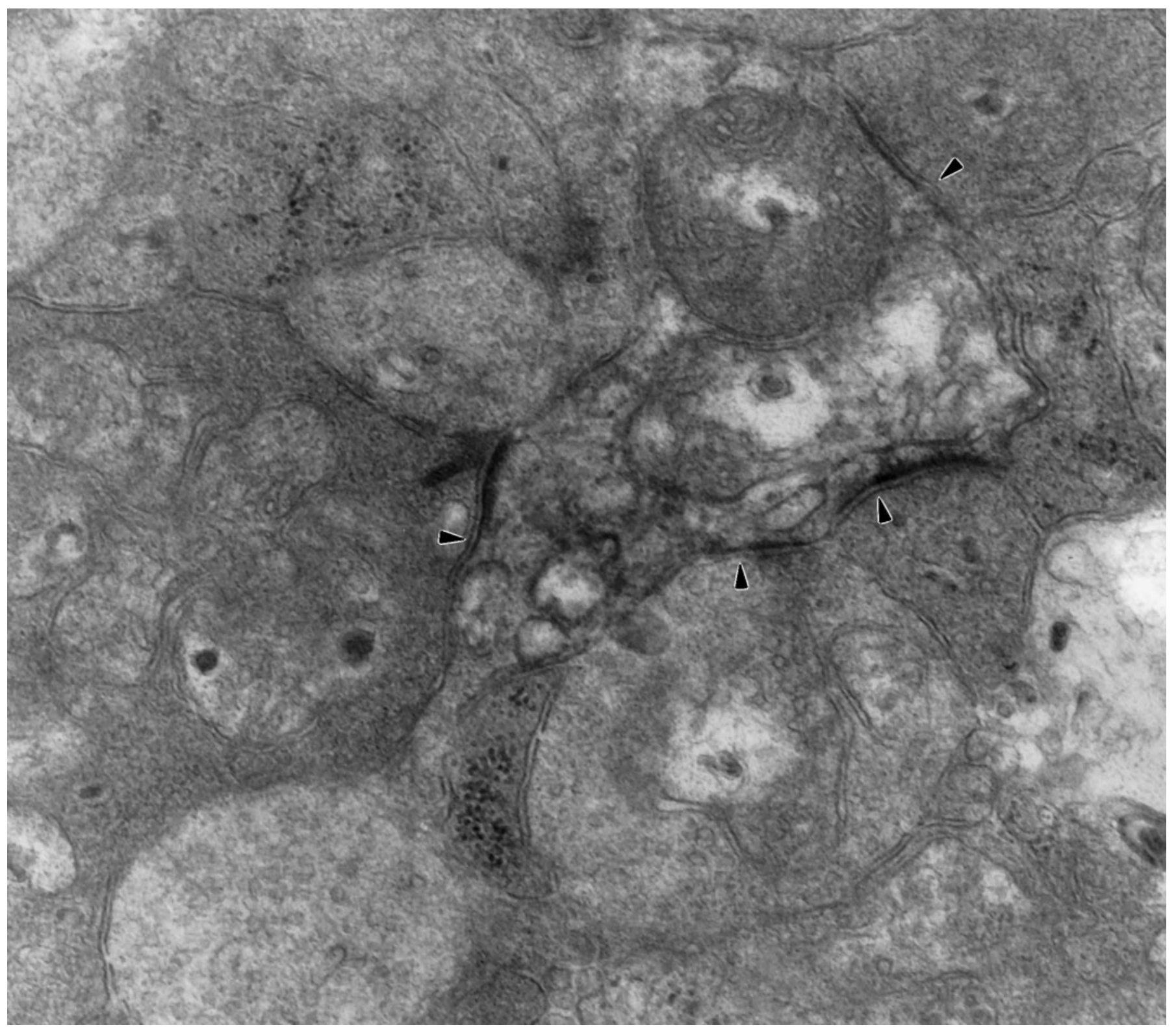

Figure 5. Three synaptic inputs and, possibly, a fourth onto a labeled parasol ganglion cell dendrite are indicated by arrowheads. A bipolar cell makes a dyad synapse on the left, and two amacrine cells, one pale and one dark, are presynaptic below. The synaptic density at the top right is less well defined $(60,000 \times)$.

narrow stratum of the IPL; the ON subtypes used in this study ramified just below the center of the IPL, at $60-65 \%$ of the distance between the inner nuclear layer (INL) and the ganglion cell layer (GCL).

It was particularly important to distinguish the injected cells from garland cells because they receive a majority of their inputs from amacrine cells (Sterling et al., 1994), like the cells in our study (Table 1). We identified our injected cells as parasol cells rather than garland cells based on morphological criteria established using the Golgi method. Polyak (1941) found that garland cells had smaller perikarya and much less densely branched dendritic arbors than parasol cells. Although the two types could stratify at the same levels of the inner plexiform layer, the garland cells had larger dendritic arbors than parasol cells at the same eccentricity. Boycott and Dowling (1969) compared a garland cell, which they called unistratified, with a parasol cell, their stratified diffuse type, at the same eccentricity and confirmed these findings. Kolb et al. (1992) described two ganglion cells similar to garland cells, G8 and G16, in whole-mount preparations of the human retina. They proposed that both correspond to Polyak's garland cells and showed that they were different from parasol cells, which they called $\mathrm{M}$ cells.

\section{Synaptic inputs to ON-parasol ganglion cells}

The ganglion cell dendrites were always postsynaptic; the synaptic inputs to $5 \mathrm{ON}$-parasol cells are summarized in Table 1 . The first parasol cell was sectioned in a sliding microtome. The sections were remounted, and sections containing the proximal and distal dendrites were compared. Both regions received a very similar proportion of their input from amacrine cells (see Table 1, cell 1). Weber and Stanford (1994) had shown that there was no change in the proportion of amacrine cell input in various regions of the 


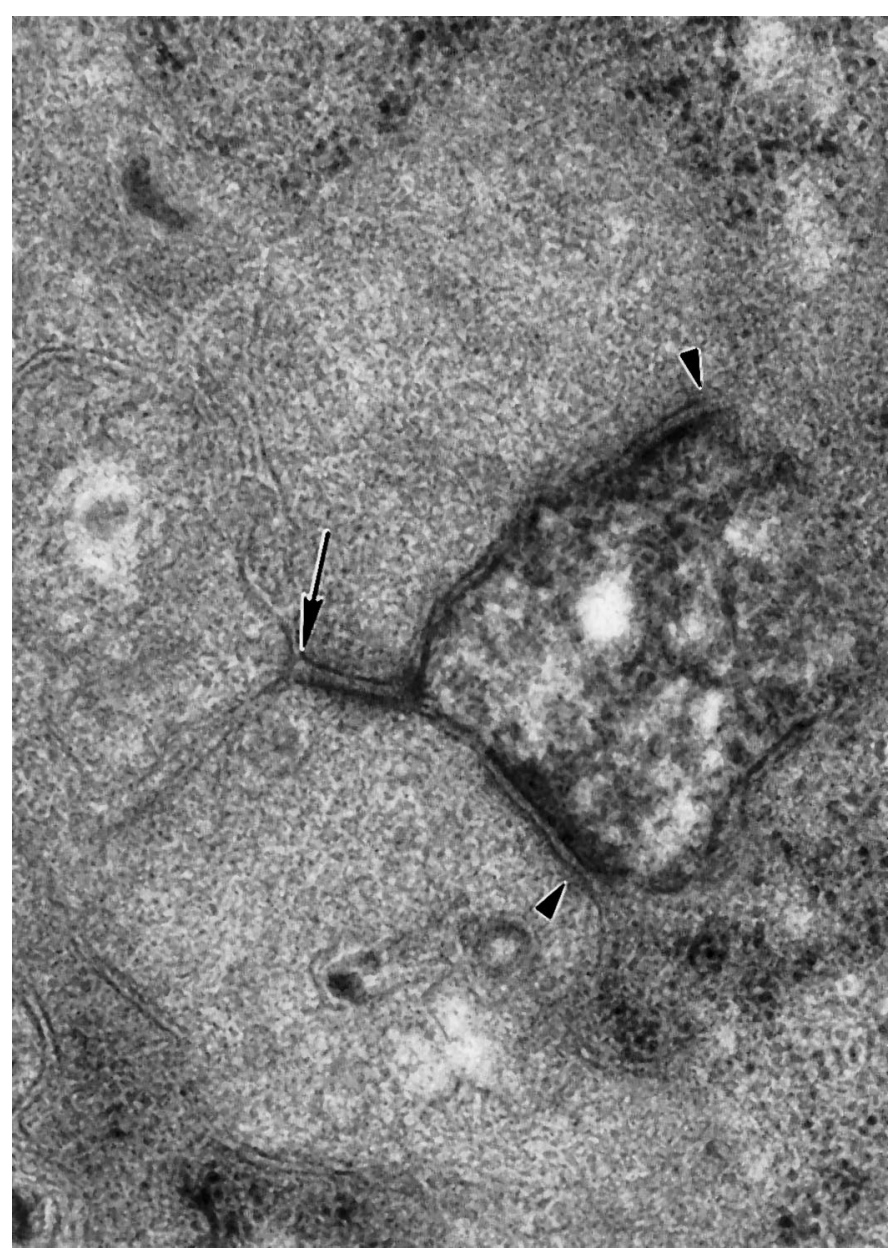

Figure 6. Two amacrine cell processes make synapses onto a labeled parasol ganglion cell dendrite (arrowheads). The upper amacrine cell process also makes a synapse onto the lower cell (arrow; 60,000×).

dendritic trees of $\alpha$ ganglion cells in the cat retina using threedimensional reconstruction. Because the same appeared to be true for the parasol cells, the remaining cells were not sampled systematically.

Figure 2 shows a bipolar cell synapse onto a labeled parasol cell dendrite. Rod bipolar cell axons do not costratify with parasol cell dendrites, and Grünert and Martin (1991) did not see direct synapses from rod bipolar cells onto ganglion cells in the macaque retina. Kolb and Dekorver (1991) have shown that midget bipolar cells in the parafovea provide input only to midget ganglion cells. The presynaptic bipolar cells, therefore, are likely to be diffuse cone types. DB4 or DB5 are expected based on the depth of their axonal arbors in the IPL (Boycott and Wässle, 1991).

A majority of inputs to parasol cells were from amacrine cells at conventional synapses. One type of presynaptic amacrine cell was relatively electron-dense and irregularly shaped (Fig. 3). Because we had selected ganglion cells from areas where there were no labeled amacrine cells, we were confident that this electron density did not result from tracer coupling. It is possible that these processes originated from AII amacrine cells because they are also relatively electron-dense. Wässle et al. (1995) saw two examples of unidentified processes receiving synapses from AII amacrine cells in stratum 3 of the macaque IPL, and these might have been ON parasol ganglion cell dendrites. Because $>98 \%$ of the output synapses of AII amacrine cells were found in the outer two strata of the IPL, however, it is more likely that another type of amacrine cell is the source of the electron-dense processes contacting parasol cells. Other presynaptic amacrine cells were more electron-lucent (Fig. 4).

In some cases, synaptic inputs appeared to be clustered on parasol ganglion cell dendrites, but this was not analyzed quantitatively (Fig. 5). In some instances, a bipolar cell presynaptic to a parasol ganglion cell and an amacrine cell received a feedback synapse from the same amacrine cell (Fig. 2). There were also feedforward synapses, that is, amacrine cells that received input at the same ribbon synapse as the parasol ganglion cell dendrite and also made a synapse onto the same ganglion cell dendrite. Figure 6 shows two amacrine cell processes that are presynaptic to a labeled parasol ganglion cell dendrite, and one of these amacrine cell processes also makes a synapse onto the other. In addition, there were amacrine cells that made synapses onto parasol ganglion cell dendrites and also onto the bipolar cells that provided input to those ganglion cell dendrites.

\section{Gap junctions of ON-parasol ganglion cells}

The ON-parasol ganglion cell dendrites also made gap junctions with amacrine cell processes. These were typical of gap junctions in the IPL and elsewhere in the CNS (Marc et al., 1988). Figure 7 shows one of these gap junctions onto the proximal dendrite of an electron-lucent amacrine cell that contains microtubules. The inner leaflets of the membranes were straight, parallel, and had a higher electron density than unspecialized membrane. The junctions were $\sim 20 \mathrm{~nm}$ in width (Fig. 8). There were cytoplasmic densities associated with the junctions in both the amacrine cells and the parasol ganglion cells. Figure 9 shows another gap junction onto an amacrine cell process with very similar ultrastructure. These resembled the dendrites of wide-field amacrine cells such as the A19 type that have been shown to contact $\alpha$ ganglion cells in the cat retina (Kolb and Nelson, 1993; Freed et al., 1996). The gap junctions were made by relatively electron-lucent amacrine cells that did not resemble AII amacrine cell processes. Thus, we agree with Wässle et al. (1995), who found no gap junctions between AII amacrine cells and ganglion cells in macaque retina.

The amacrine cell processes were relatively large in diameter at the points where the gap junctions were found, averaging $1.12 \pm$ 0.39 (SD) $\mu \mathrm{m}$ when measured in their short axes. This finding suggests that gap junctions were located on the proximal amacrine cell dendrites, as does the observation of ribosomes in the amacrine cell dendrite in Figure 7. In both instances illustrated here, the amacrine cell and ganglion cell dendrites were approximately perpendicular, but there were also examples in which the two dendrites were more nearly parallel, as would be expected if the dendrites cofasciculated as described by Dacey and Brace (1992). Chemical synapses from other amacrine cells were often observed in the vicinity of gap junctions as in Figure 9, but there were no examples of mixed synapses, that is, single amacrine cells making both gap junctions and conventional synapses onto the parasol ganglion cells.

The gap junctions were $0.34 \mu \mathrm{m}$ long, on average. Assuming that the junctions are circular and that the density of connexons is the same as in a freeze-fracture micrograph from the macaque IPL (Peters et al., 1991), 359 connexons would be expected per junction. If each of these had a conductance of $50 \mathrm{pS}$, as they do elsewhere in the retina (McMahon et al., 1989), the conductance of each junction would be $17.9 \mathrm{nS}$ when it was fully open. Because parasol cells typically have an input resistance of $\sim 200 \mathrm{M} \Omega$ (Z. 

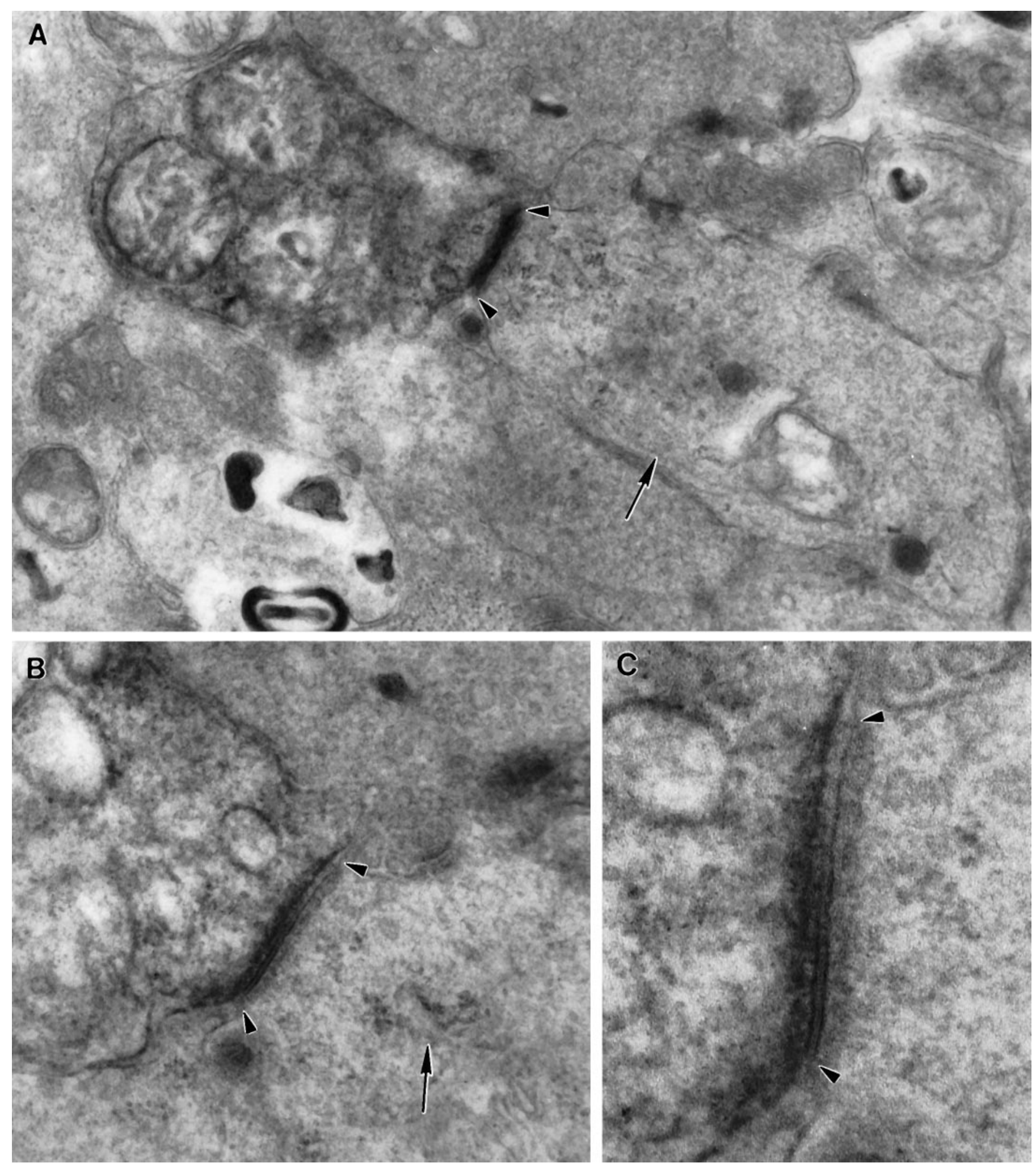

Figure 7. A gap junction (arrowhead) between a labeled parasol ganglion cell dendrite and an electron-lucent amacrine cell process containing microtubules (arrow) cut in a longitudinal section. $A$, The large diameter of the process at the junction and the ribosomes nearby indicates that this is a proximal amacrine cell dendrite $(40,000 \times) . B$, The portion of the dendrite near the gap junction containing ribosomes $($ arrow) is shown at $75,000 \times$. $C$, The junction is shown at $150,000 \times$; note the cytoplasmic densities on both sides. 


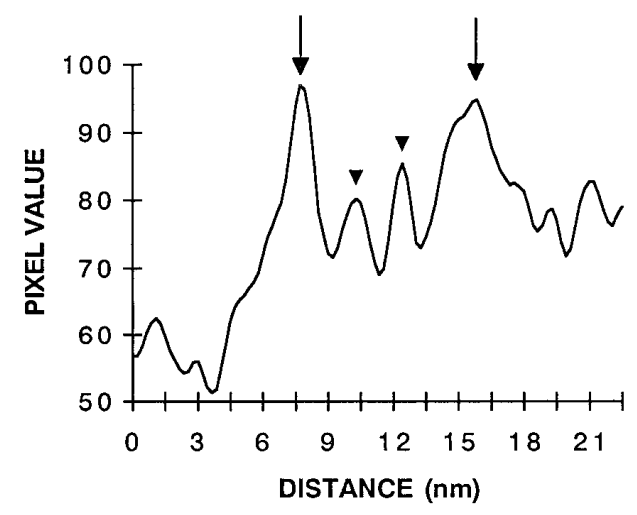

Figure 8. Densitometric scan of the gap junction illustrated in Figure 7. The peaks (arrows) indicate the densest portions of the inner leaflets. The outer leaflets (arrowheads) were not as well defined as they would have been with conventional fixation and en bloc staining, however, and it was not always possible to visualize the gap between them. The baseline is higher on the right because of the peroxidase reaction product in the labeled parasol cell.
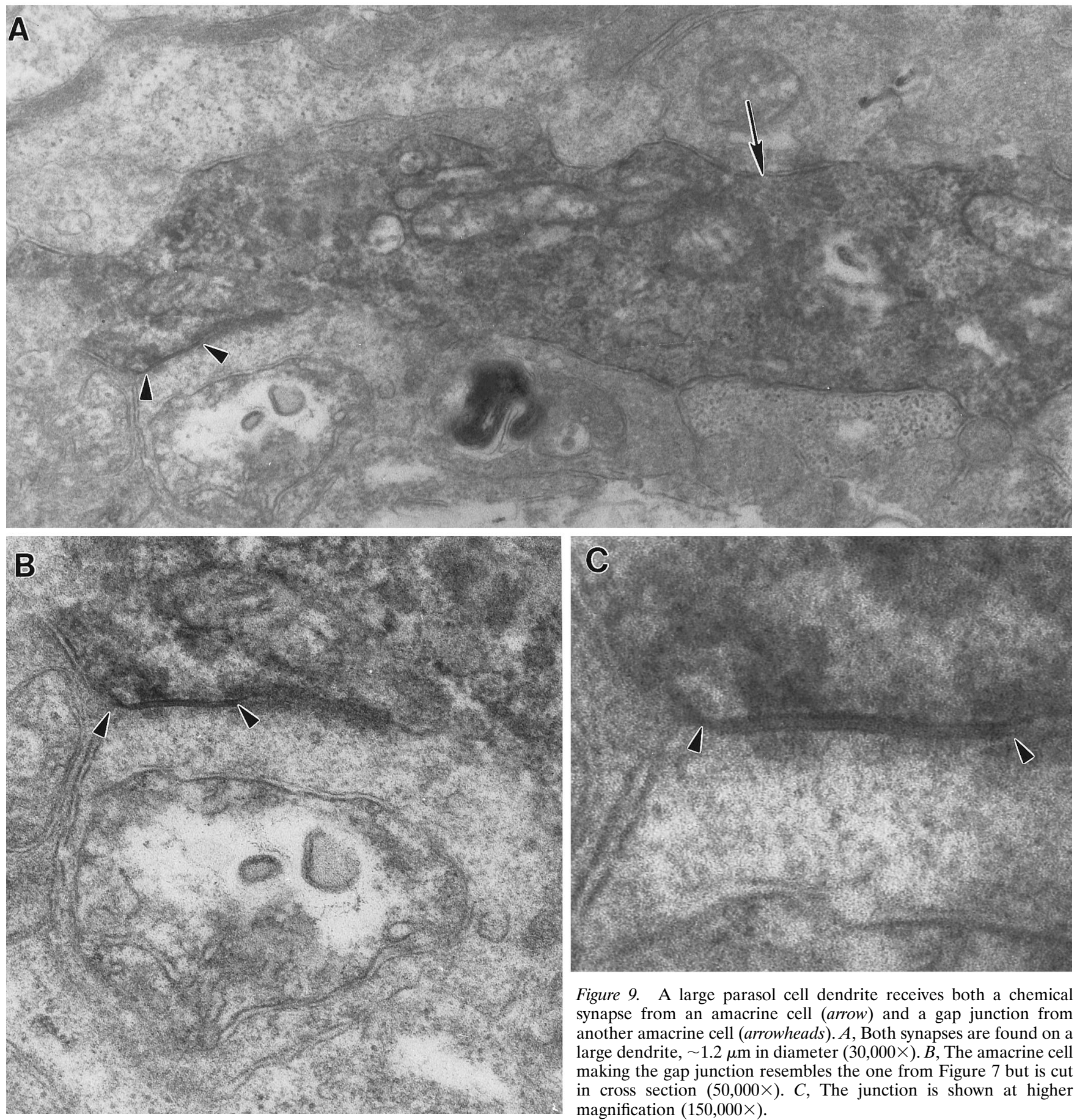

Figure 9. A large parasol cell dendrite receives both a chemical synapse from an amacrine cell (arrow) and a gap junction from another amacrine cell (arrowheads). A, Both synapses are found on a large dendrite, $\sim 1.2 \mu \mathrm{m}$ in diameter $(30,000 \times)$. $B$, The amacrine cell making the gap junction resembles the one from Figure 7 but is cut in cross section $(50,000 \times)$. $C$, The junction is shown at higher magnification $(150,000 \times)$. 


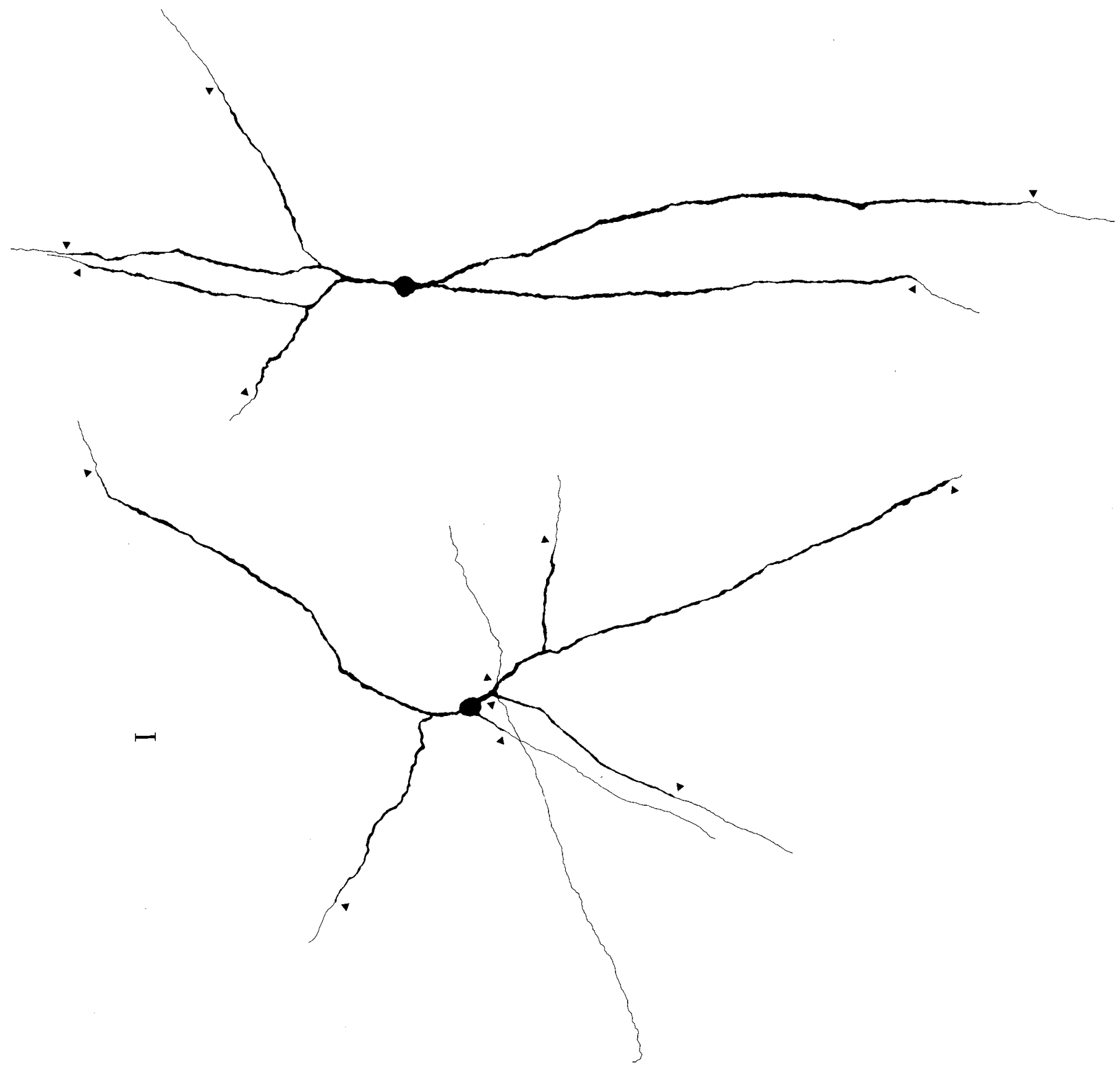

Figure 10. Camera lucida drawings of two of the large subtypes of G6-gly-IR amacrine cells from the peripheral retina of Macaca fascicularis. The retinas were isolated, fixed in periodate-lysine-paraformaldehyde, and labeled as described previously (Marshak et al., 1990). Note the large diameter of the dendrites. The axons (arrowheads) typically arose from the tips of the dendrites, but they can also arise more proximally, as indicated in the lower drawing. The axons could only be followed for a short distance through the plexus of labeled processes. Scale bar, $10 \mu \mathrm{m}$.

Zhou, personal communication), each junction could produce up to a $3.6 \mathrm{mV}$ change in the membrane potential of the parasol ganglion cell for each millivolt of transjunctional voltage.

\section{G6-gly-IR amacrine cells}

As we described previously (Marshak et al., 1990), antisera to the glycine-extended cholecystokinin precursor (G6-gly) labeled two distinct types of amacrine cells. Their processes formed two plexuses centered at 30 and $65 \%$ of the IPL depth, the same levels as parasol ganglion cell dendrites (Watanabe and Rodieck, 1989). One type of G6-gly-IR amacrine cell had ovoid perikarya $\sim 10-15$ $\mu \mathrm{m}$ in diameter and two to three short, primary dendrites that typically branched once and gave rise to longer, unbranched dendrites with a large diameter. One population had perikarya in the INL and processes in stratum 2 of the IPL, and the second had perikarya in the GCL and processes in stratum 4 of the IPL. In whole mounts (Fig. 10), thin, axon-like processes were seen arising from the tips of the dendrites and occasionally from other parts of the dendrites, but it was not possible to follow these to their terminations. These large, unistratified cells were virtually identical in their morphology and stratification to the large, poly- 

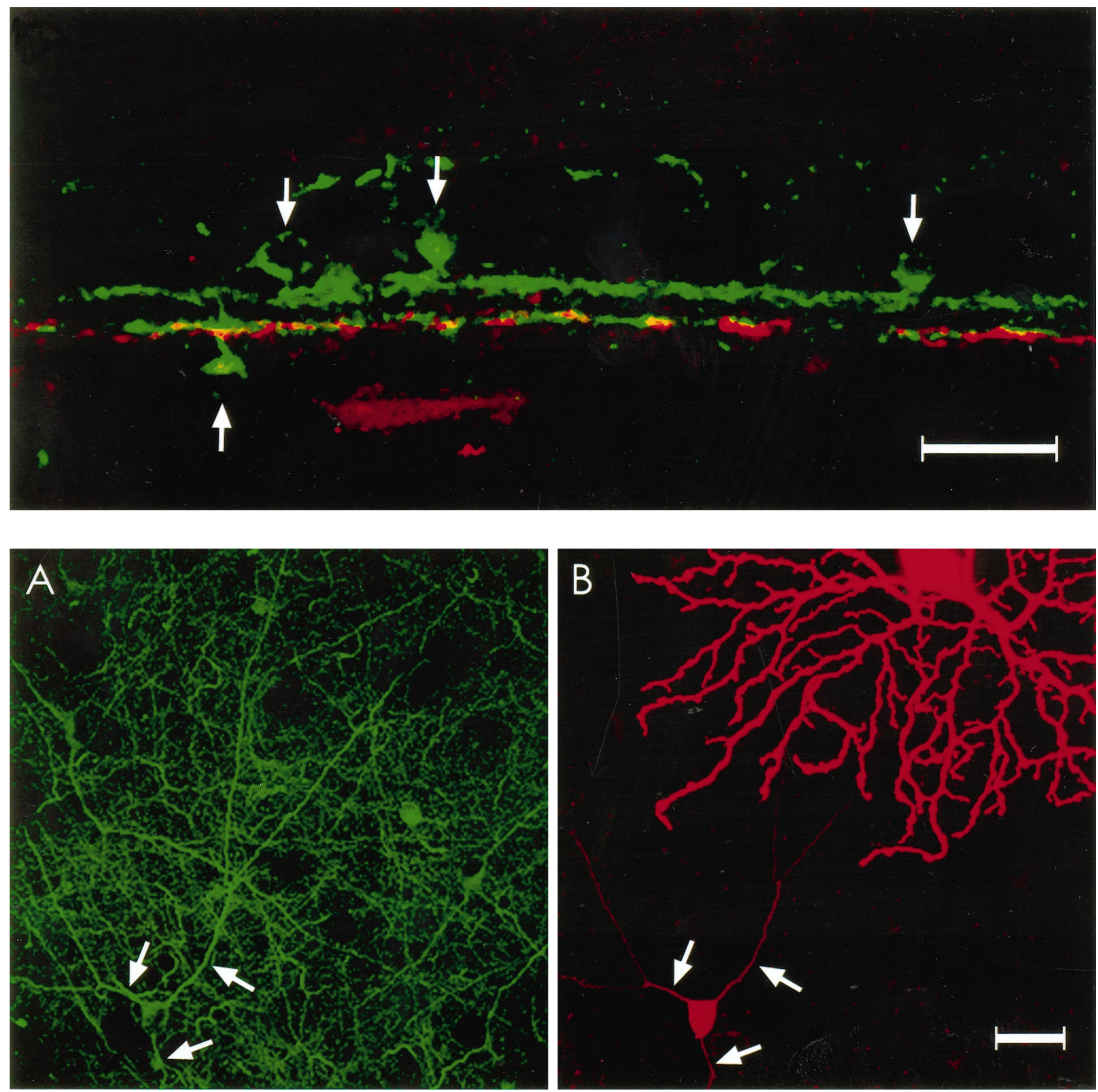

Figure 11. Top. Lucifer yellow-injected ON-parasol ganglion cell dendrites (red) were narrowly costratified with the inner set of G6-gly-IR processes (green) in a double-labeled vertical section of macaque retina. G6-gly-IR perikarya (arrows) were found in the inner nuclear layer and the ganglion cell layer. Dendrites from blue cone bipolar cells were also visible in the distal inner nuclear layer and outer plexiform layer. This confocal image represents a stack of optical sections spanning $4.5 \mu \mathrm{m}$. Scale bar, $25 \mu \mathrm{m}$.

Figure 12. Bottom. A, Left, Green processes indicate G6-gly immunoreactivity in a whole-mount preparation. Arrows indicate the primary dendrites of a large G6-gly-IR amacrine cell. Note that most of the other processes are smaller in diameter. $B$, Right, The same volume of tissue as $A$, containing a Neurobiotin-injected ON-parasol ganglion cell (top right) with a large, tracer-coupled amacrine cell (bottom left). Arrows indicate the same dendrites as in $A$, which are double-labeled. Both images represent a reconstructed stack of optical sections spanning from the ganglion cell layer to the middle of the IPL. Scale bar, $25 \mu \mathrm{m}$.

axonal amacrine cells that were found to be tracer-coupled to parasol ganglion cells by Dacey and Brace (1992). These cells have also been described in three studies using the Golgi method, the first by Boycott and Dowling (1969), who called them unistratified amacrine cells. Mariani (1990) described a cell called "wispy" that ramified in the center of the IPL but was otherwise very similar, and Kolb et al. (1992) described semilunar type 3 cells that were similar to the G6-gly-IR cell ramifying in stratum 4. The second 


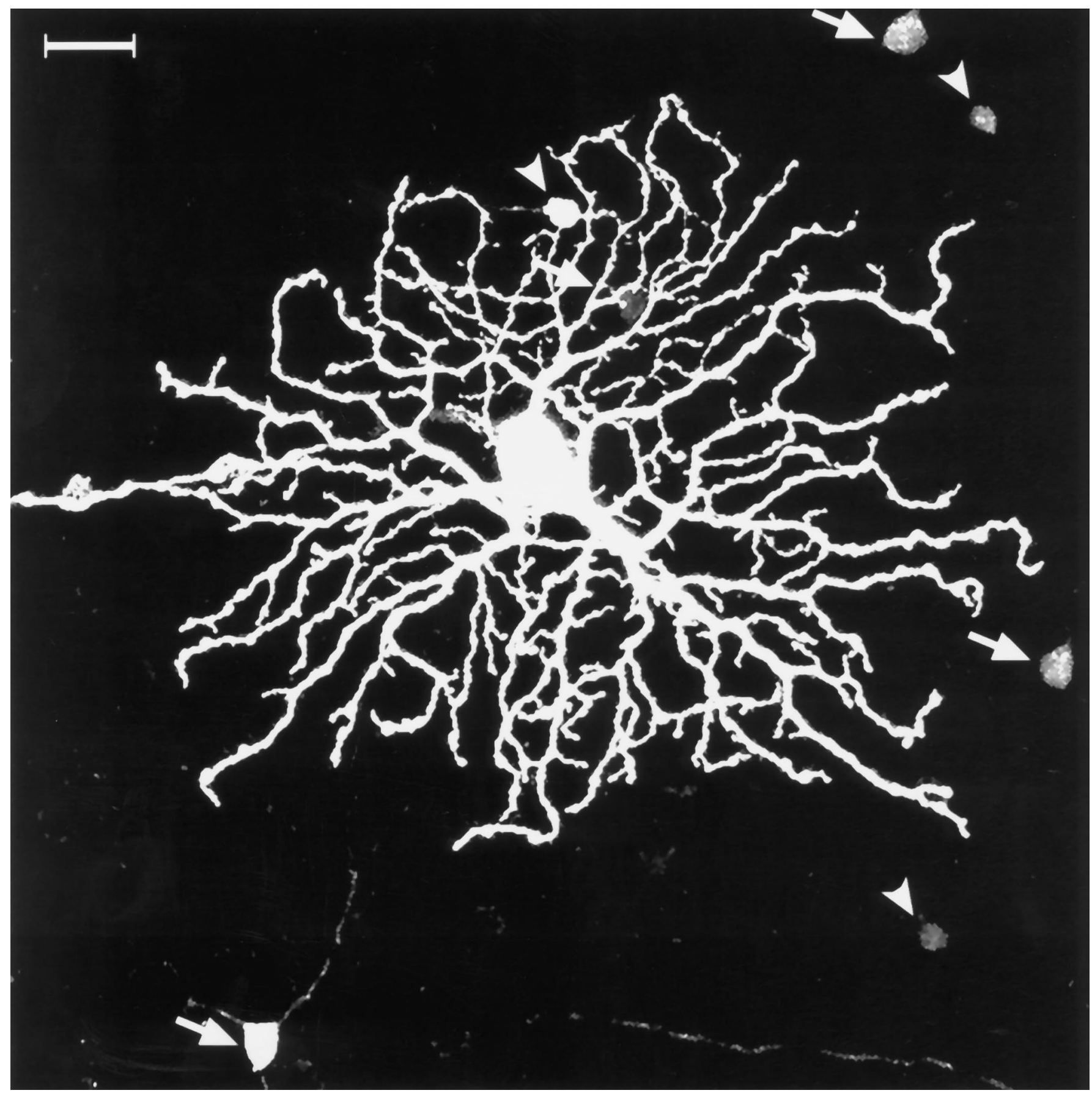

Figure 13. The same parasol cell as in Figure 12 from a different scan of a larger area of retina showing only the Neurobiotin signal (white). The smaller tracer-coupled cells (arrowheads) were G6-gly-negative, and in this area were all located in the inner nuclear layer. The larger tracer-coupled cells (arrows) were G6-gly-IR and were found in the ganglion cell layer or the lower half of the IPL. This image represents a reconstructed stack of optical sections spanning from the ganglion cell layer to the inner nuclear layer. Scale bar, $25 \mu \mathrm{m}$.

type of G6-gly-IR amacrine cell was smaller and also had approximately half of its perikarya in the INL and half in the GCL. Regardless of the positions of the perikarya, these amacrine cells contributed thin, varicose dendrites to both plexuses. These smaller, bistratified G6-gly-IR cells resembled the wavy, multistratified type 2 cells of Mariani (1990) and the A14 cells of Kolb et al. (1992). We have also shown previously that the G6-gly-IR amacrine cells direct $41 \%$ of their output to ganglion cells and make gap junctions (Marshak et al., 1990).

To determine whether the G6-gly-IR amacrine cells and para- sol cells were costratified, we analyzed $4 \mathrm{ON}$-parasol cells in double-labeled vertical sections from macaque retina. Figure 11 is a vertical section showing that Lucifer yellow-labeled ON-parasol cell dendrites are very narrowly costratified with the inner set of G6-gly-IR processes. The parasol cell dendrites traveled among the G6-gly-IR processes, apparently making many contacts. We could not differentiate the dendrites of the small, bistratified G6-gly-IR amacrine cells from the axons of the larger labeled amacrine cells, however, because both ramified at the same level in the IPL. Because no amacrine cells were labeled after Lucifer 


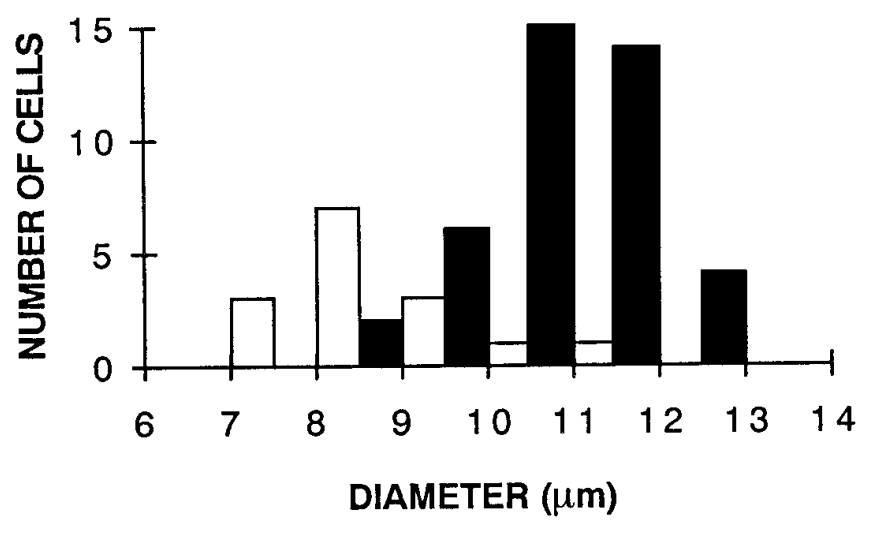

Figure 14. Soma size histogram of amacrine cells tracer-coupled to Neurobiotin-injected parasol ganglion cells. Double-labeled, G6-gly-IR amacrine cells (filled bars, $n=41$ ) formed a distinct group ( $t$ test, $p<$ 0.001 ) based on soma size, with a mean diameter of $10.8 \pm 1.0 \mu \mathrm{m}$. Tracer-coupled amacrine cells that were not G6-gly-IR (open bars, $n=14$ ) had a soma diameter of $8.8 \pm 1.2 \mu \mathrm{m}$.

yellow injections into parasol cells, Neurobiotin was used for the remainder of the experiments in order to identify the tracercoupled amacrine cells.

When Neurobiotin was injected, heterotypic tracer-coupling was observed in $12 \mathrm{ON}$-parasol cells from 3 living retinas, each from a different macaque. As described by Dacey and Brace (1992), both large and small amacrine cells were labeled after parasol cells were injected. Some of the tracer-coupled cells were also labeled with antiserum to G6-gly. The perikarya and primary dendrites of the double-labeled amacrine cells were completely filled with Neurobiotin. The G6-gly labeling was distributed differently than the Neurobiotin in some of these cells. G6-gly labeling was consistently observed in the Neurobiotin-labeled large dendrites, but not always in their perikarya (Fig. 12). All but one of the double-labeled amacrine cells were found in the ganglion cell layer or the inner half of the IPL. Other tracer-coupled amacrine cells were not G6-gly-IR, and most of them were found in the inner nuclear layer or the outer half of the IPL (Fig. 13). Double-labeled cells $(n=41)$ had a mean soma diameter of $10.8 \pm 1.0 \mu \mathrm{m}$, and G6-gly-negative tracer-coupled amacrine cells $(n=15)$ had a mean soma diameter of $8.8 \pm 1.2 \mu \mathrm{m}$ (Fig. 14). The tracer-coupled amacrine cells also fell into two distinct groups $(t$ test, $p<0.001)$. Therefore, the larger tracer-coupled amacrine cells are likely to contain cholecystokinin, but the smaller ones are not. The double-labeled amacrine cells were classified as the larger of the two types of G6-gly-IR amacrine cells, but the smaller tracer-coupled amacrine cells were not labeled sufficiently to observe the morphological details necessary to classify them.

The primary dendrites of double-labeled cells ranged from 0.79 to $1.52 \mu \mathrm{m}$ in diameter, but these made up only a small fraction of the dense meshwork of G6-gly-IR processes that surrounded the dendritic trees of injected parasol cells (Fig. 12A). Many of these other processes were narrower than the dendrites of the doublelabeled cells and, therefore, were the axons of the larger amacrine cells and the dendrites of the smaller, bistratified amacrine cells. We were certain that the large G6-gly-IR dendrites were in contact with parasol cell dendrites because of the tracer coupling. We also wanted to determine whether there was more contact between G6-gly-IR processes and parasol cell dendrites than would be expected by chance. We used 13 reconstructed stacks consisting of $0.3-0.5 \mu \mathrm{m}$ optical sections spanning $\sim 5 \mu \mathrm{m}$. Con- trol images had $6.1 \%$ fewer yellow pixels than the original images. The differences were small but consistent; control images had significantly less contact, as measured by the number of yellow pixels, than the originals (paired $t$ test, $p=0.006$ ).

\section{Cholinergic amacrine cells}

The cholinergic, or starburst, amacrine cells are also likely to contact parasol ganglion cells based on their stratification pattern and synaptic connections (Mariani and Hersh, 1988; Rodieck and Marshak, 1992). To analyze the interactions between cholinergic amacrine cells and parasol cells, we labeled tissue containing Neurobiotin-filled parasol cells with antiserum to choline acetyltransferase (ChAT). First, we examined vertical sections of this material to determine whether the cholinergic processes ramified at the same level of the IPL as parasol cell dendrites. We found that dendrites from ON-parasol cells were narrowly costratified with the innermost set of cholinergic processes (Fig. 15).

We used whole-mount preparations to examine the interactions of the ChAT-IR amacrine cell processes and the parasol ganglion cell dendrites in greater detail. We used stacks of 10-15 optical sections like Figure 16 rather than single sections so that we could see the two sets of dendrites in their entirety. We had shown that parasol cell dendrites and ChAT-IR processes were confined to the same narrow stratum of the IPL and, therefore, we were confident that the dendrites were not artifactually superimposed. This was confirmed in the individual optical sections that made up the reconstructed stack. In some instances, a parasol cell dendrite and a cholinergic process were intertwined and made several appositions. The appositions were frequently located on the ChAT-IR varicosities. The cholinergic processes do not cofasciculate with parasol cell dendrites as extensively as they do with $\alpha$ ganglion cell dendrites in cat (Vardi et al., 1989), but there appear to be selective contacts in both species. We analyzed 9 areas from 3 ON-parasol cells, and control images (Fig. 17) had 28.1\% fewer yellow pixels than the original images. The controls were significantly lower than the original images $(p=0.001)$.

These results indicate that there is more total area of contact between the cholinergic and G6-gly-IR processes and the parasol cell dendrites than would be expected from chance. It is likely that some of the appositions with the ChAT-IR and G6-gly-IR processes are sites of synapses onto parasol ganglion cell dendrites, but this can only be proven by electron microscopic doublelabeling experiments. It is also uncertain what percentage of the amacrine cell synapses we observed in the electron microscope were from these identified amacrine cells.

\section{DISCUSSION Synaptic inputs to ON-parasol cells}

ON-parasol cells in peripheral retina received the majority of their synaptic inputs from amacrine cells, but they are reported to receive most of their input from bipolar cells in the parafovea (Sterling et al., 1994). This would not be expected simply on the basis of size, based on studies of cat retinal ganglion cells at different eccentricities (Kier et al., 1995). It may result from the higher density of bipolar cells relative to amacrine cells in the parafovea (Krebs and Krebs, 1989; Curcio and Allen, 1990; Martin and Grünert, 1992), but Dubin (1970) found that the ratio of amacrine cell to bipolar cell synapses does not change with eccentricity. It is more likely that the differences in the number of bipolar cell inputs reflect the different pattern of synaptogenesis in the central macaque retina (for review, see Crooks et al., 1995). Bipolar cell synapses are the first ones to form in the macaque fovea, but amacrine cells form first more peripherally. 

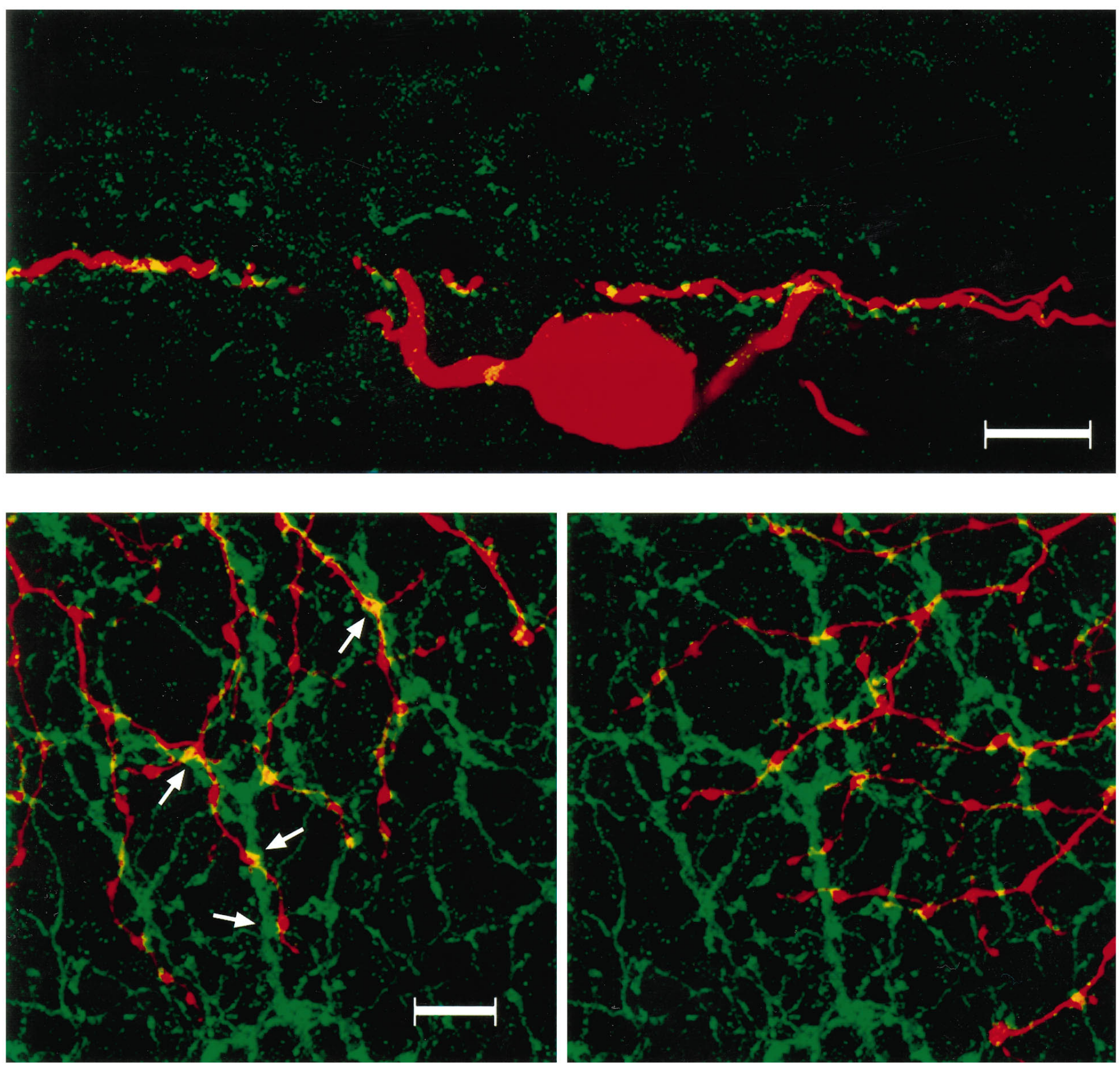

Figure 15. Top. A double-labeled vertical section containing a Neurobiotin-injected ON-parasol ganglion cell (red) and amacrine cell processes labeled with antisera to ChAT (green). The inner set of cholinergic processes was narrowly costratified with the ON-parasol cell dendrites. This confocal image represents a reconstructed stack of optical sections spanning $1 \mu \mathrm{m}$ in depth. Scale bar, $25 \mu \mathrm{m}$.

Figure 16. Bottom left. A double-labeled whole mount with Neurobiotin-filled parasol ganglion cell dendrites (red) and ChAT-IR amacrine cell processes (green). The parasol cell dendrites appear to follow the cholinergic processes, making repeated contacts (arrows). Areas of overlap between the two sets of processes appear yellow. The number of yellow pixels was counted to determine the amount of contact. This confocal image represents a reconstructed stack of optical sections through the inner IPL. Scale bar, $25 \mu \mathrm{m}$.

Figure 17. Bottom right. Control image for Figure 16 at the same scale. The Neurobiotin-filled parasol cell dendrites (red image) have been rotated $90^{\circ}$ clockwise relative to the cholinergic processes (green image), which are in the same orientation as Figure 16. The yellow pixels in this image represent random overlap of the two sets of processes. The average amount of contact attributable to chance was $28.1 \pm 11.9 \%$ less than in the original images.

Thus, if parasol cells receive synapses from the first presynaptic cells available, their patterns of input would be different in central and peripheral retina.

The synaptic connections of parasol cells in the peripheral baboon retina and $\alpha$ ganglion cells in the cat retina were quite similar. Three groups found that $\alpha$ cells receive $80 \%$ or more of their input from amacrine cells (Watanabe et al., 1985; Freed and Sterling, 1988; Kolb and Nelson, 1993). Weber and Stanford (1994) found only $62 \%$ amacrine cell input, however, probably because their $\alpha$ cells were very densely labeled and postsynaptic densities could not be used to 


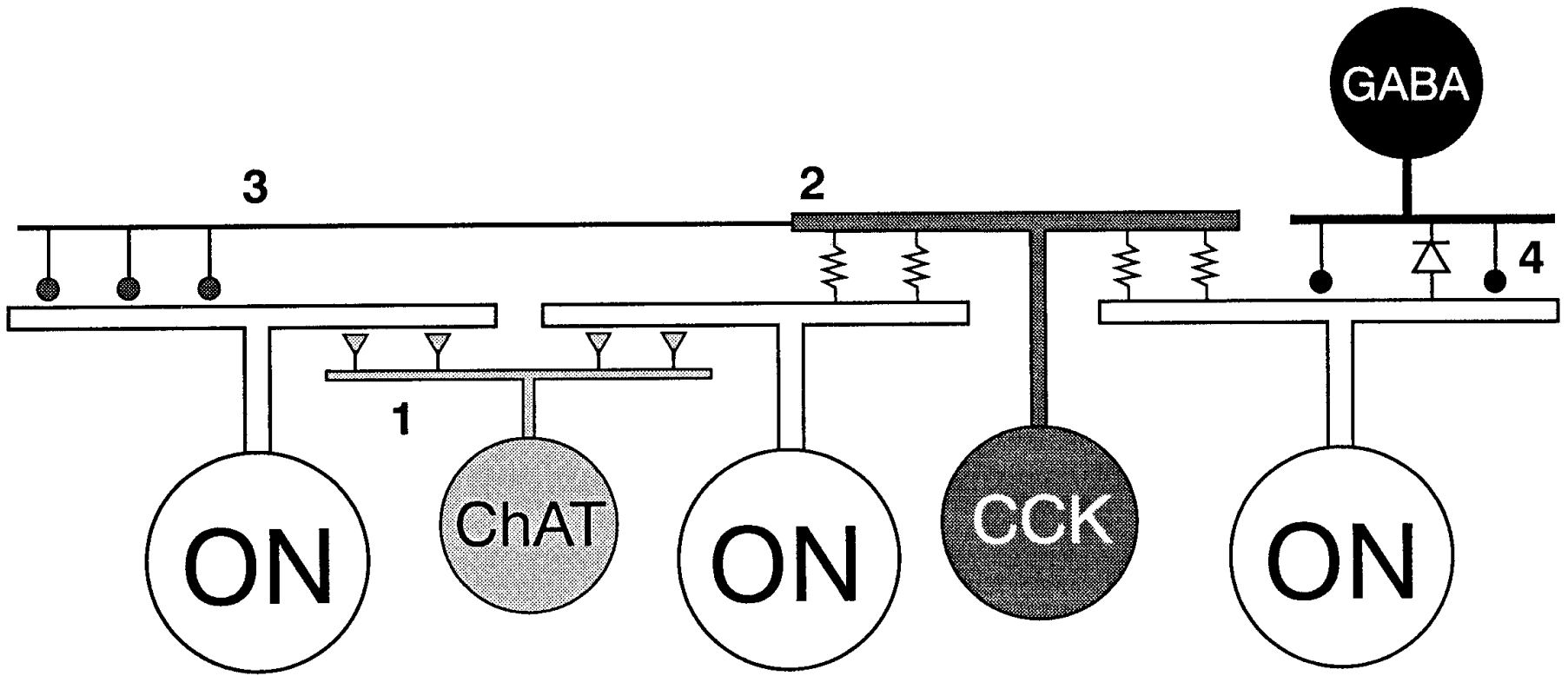

Figure 18. Summary diagram of the proposed synapses from amacrine cells to ON-parasol ganglion cells. The synapses of bipolar cells and the synapses between amacrine cells have been omitted. The displaced amacrine cell labeled ChAT (light gray) probably contains both acetylcholine and GABA (Rodieck and Marshak, 1992). Based on the actions of acetylcholine in cat retina, it is expected to make excitatory synapses (filled triangles) onto the ganglion cells (1). The larger displaced amacrine cell labeled CCK (dark gray) is G6-gly-positive and makes gap junctions (resistors) with the proximal dendrites of the ON-parasol cell at (2). It contains cholecystokinin and, possibly, GABA. Its axons make inhibitory synapses (filled circles) onto parasol ganglion cell dendrites, mainly those outside of its dendritic field (3). The amacrine cell labeled GABA in the inner nuclear layer (black) represents the smaller tracer-coupled amacrine cell. It might make both inhibitory synapses and rectified gap junctions (diodes) with the parasol ganglion cell dendrites (4). Dacey and Brace (1992) suggested that it might make gap junctions with the CCK amacrine cells rather than the parasol ganglion cells.

identify synapses (Freed and Sterling, 1988). One of the amacrine cells presynaptic to parasol cells in our study was relatively electronlucent and contained microtubules, like the wide-field amacrine cells that contact $\alpha$ cells (Kolb and Nelson, 1993; Freed et al., 1996). We also found that parasol cells make extensive contacts with cholinergic amacrine cells like $\alpha$ cells (Vardi et al., 1989). Finally, we confirmed that parasol cells, like $\alpha$ cells, are tracer-coupled to amacrine cells, and we found the gap junctions that mediate this effect. These findings add to the growing body of evidence that parasol cells and $\alpha$ cells are homologous (for review, see Peichl, 1991; Rodieck et al., 1993).

\section{Identity and functions of amacrine cells presynaptic to ON-parasol cells}

One of the amacrine cells coupled to the ON-parasol cells was the large G6-gly-IR type that we described previously (Marshak et al., 1990). These are very similar to the long-range neurofibrillarstaining cells of the cat, which are labeled after Neurobiotin injections into $\alpha$ ganglion cells (Vaney, 1991). Like Dacey and Brace (1992), we saw numerous contacts between their dendrites and parasol cell dendrites in these experiments. Cholecystokinin has potent, inhibitory effects on the activity of brisk sustained and brisk transient retinal ganglion cells in cats (Thier and Bolz, 1985), and parasol cells would be expected to respond similarly. A19 and A22 amacrine cells in the cat retina are also quite similar to the large G6-gly-IR type (Kolb et al., 1981; Vaney et al., 1988), and they make chemical synapses onto $\alpha$ ganglion cells (Kolb and Nelson, 1993; Freed et al., 1996). The A19 and A22 cells have transient ON-OFF responses to light (Kolb and Nelson, 1985; Freed et al., 1996), and so should the large, G6-gly-IR amacrine cells. There are transient hyperpolarizations in parasol cells, one producing a discontinuity in firing after the initial response and another at the offset of the stimulus (deMonasterio, 1978), and these may represent input from G6-gly-IR amacrine cells.
The ChAT-positive displaced amacrine cells also costratified with the ON-parasol cells and made extensive contacts. The cholinergic synapses are likely to be excitatory (for review, see Kaneda et al., 1995). Cholinergic displaced amacrine cells respond to light stimuli in the receptive field center with a transient depolarization followed by a sustained depolarization (Bloomfield, 1992; Taylor and Wässle, 1995; Peters and Masland, 1996). These cholinergic cells, therefore, should excite ON-parasol cells, particularly at the beginning of the light responses. In other mammals, cholinergic amacrine cells respond well to moving and other rapidly changing stimuli (for review, see O'Malley and Masland, 1993). Their inputs could account, at least in part, for the high sensitivity of parasol cells to the same kinds of stimuli (Scobey and Horowitz, 1976; Scobey, 1981).

There is a major GABAergic input to parasol cells. The two strata of the IPL where the parasol cells ramify contain the highest density of synapses from GABA-IR amacrine cells onto ganglion cells (Koontz and Hendrickson, 1990), and synapses have been observed from GABA-IR amacrine cells onto parasol cells identified by three-dimensional reconstruction (Kolb and Crooks, 1992). GABA A $_{\mathrm{A}}$ receptors of ON-parasol cells have been described in both anatomical (Grünert et al., 1993) and physiological (Zhou et al., 1994) experiments. Some of these synapses might be made by amacrine cells that also contain ChAT-IR or G6-gly-IR. Others may be made by the smaller, tracer-coupled amacrine cells or additional types of amacrine cells.

\section{Gap junctions between amacrine cells and parasol ganglion cells}

We also found gap junctions between parasol cells and amacrine cells. Gap junctions had been observed between the two postsynaptic elements at dyad synapses (Reale et al., 1978; Raviola and Raviola, 1982), of which a majority have one process from an 
amacrine cell and another from a ganglion cell (Dowling, 1968; Koontz and Hendrickson, 1987). Although it is possible that gap junctions serve some metabolic function, they may also contribute directly to the light responses of parasol cells.

The net effect of the coupled amacrine cells might be excitatory, even though their chemical synapses onto the ganglion cells are inhibitory (Vaney, 1994). Axon-bearing amacrine cells like the large G6-gly-IR type would be particularly well suited for this purpose if the gap junctions were located on their dendrites and the output synapses on their axons. In that case, the ganglion cells that fell within the dendritic field of an amacrine cell would be excited by that amacrine cell, but those falling outside would be inhibited. According to this hypothesis, action potentials could propagate from one parasol ganglion cell to the G6-gly-IR amacrine cells and then to other parasol ganglion cells via the gap junctions, producing synchronous firing in the ganglion cells, as observed in cat (Mastronarde, 1983; Neuenschwander and Singer, 1996) and rabbit (DeVries and Baylor, 1996) retinas. Dacey and Brace (1992) also proposed that input from amacrine cells through the gap junctions enlarges the receptive-field centers of the parasol cells, thereby increasing their sensitivity to luminance contrast. The receptive-field centers of parasol cells match the dendritic fields, however (Crook et al., 1988; Croner and Kaplan, 1995). The diameter of the receptive-field center increases with dark adaptation (Gouras, 1967), and Vaney (1994) has proposed that the effect of coupling between amacrine cells and ganglion cells might be larger or more apparent in dim light. Alternatively, the gap junctions might provide additional excitation without increasing the receptive-field-center size. This would occur if the inputs via gap junctions alone were insufficient to bring the ganglion cell membrane potential to threshold and concomitant bipolar cell inputs were also required.

A second possibility is that the gap junctions enhance the inhibition of the parasol ganglion cells by the amacrine cells. This would occur if the gap junctions between the amacrine cells and the parasol ganglion cells were rectified so that they conduct more when the ganglion cells are depolarized relative to the amacrine cells (Peters et al., 1991). When the ganglion cells depolarize, the amacrine cells would also depolarize via the gap junctions and, after a brief synaptic delay, the amacrine cells would inhibit the ganglion cells. There is electrophysiological evidence for an inhibitory role for the gap junctions. Gouras (1969) saw inhibition after antidromic stimulation of the optic nerve in parasol cells but not in midget cells, which have no gap junctions (Dacey and Brace, 1992). The results of Neurobiotin injection experiments are also consistent with this hypothesis. Amacrine cells can be labeled after ganglion cell injections with positive current, but ganglion cells are rarely labeled after amacrine cell injections (Vaney, 1994; Xin et al., 1995). Because there are two types of coupled amacrine cells, our two hypotheses are not mutually exclusive. Indeed, the most parsimonious explanation is that gap junctions from the large G6-gly-IR amacrine cells mediate the excitatory interactions and gap junctions from the smaller amacrine cells mediate the inhibitory interactions.

Our model is summarized in Figure 18. There are two excitatory inputs that increase the sensitivity of parasol cells, one from the dendrites of cholecystokinin-containing cells via gap junctions and another from cholinergic cells via chemical synapses. The axons of cholecystokinin-containing amacrine cells and other types of amacrine cells make inhibitory synapses with the parasol cells. Feedback to the amacrine cells via gap junctions makes this inhibition more effective and the light responses of parasol cells more transient.

\section{REFERENCES}

Bloomfield SA (1992) Relationship between receptive and dendritic field size of amacrine cells in the rabbit retina. J Neurophysiol 68:711-725.

Boycott BB, Dowling JE (1969) Organization of the primate retina: light microscopy. Phil Trans R Soc Lond [Biol] 255:109-184.

Boycott BB, Wässle H (1991) Morphological classification of bipolar cells of the primate retina. Eur J Neurosci 3:1069-1088.

Bunt AH, Hendrickson AE, Lund JS, Lund RD, Fuchs AF (1975) Monkey retinal ganglion cells: morphometric analysis and tracing of axonal projections with a consideration of the peroxidase technique. J Comp Neurol 164:265-286.

Casagrande VA, DeBruyn EJ (1982) The Galago visual system: aspects of normal organization and developmental plasticity. In: The lesser bushbaby (Galago) as an animal model: selected topics (Haines DE, ed), pp 138-168. Boca Raton, FL: CRC.

Croner LJ, Kaplan E (1995) Receptive fields of P and M ganglion cells across the primate retina. Vision Res 35:7-24.

Crook JM, Lange-Malecki B, Lee BB, Valberg A (1988) Visual resolution of macaque retinal ganglion cells. J Physiol (Lond) 396:205-224.

Crooks J, Okada M, Hendrickson AE (1995) Quantitative analysis of synaptogenesis in the inner plexiform layer of macaque monkey fovea. J Comp Neurol 360:349-362.

Curcio CA, Allen KA (1990) Topography of ganglion cells in human retina. J Comp Neurol 300:5-25.

Dacey DM, Brace S (1992) A coupled network for parasol but not midget ganglion cells in the primate retina. Vis Neurosci 9:279-290.

Dacey DM, Lee BB (1994) The blue $\mathrm{ON}^{\prime}$ opponent pathway in primate retina originates from a distinct bistratified ganglion cell type. Nature 367:731-735.

Dacey DM, Petersen MR (1992) Dendritic field size and morphology of midget and parasol ganglion cells of the human retina. Proc Natl Acad Sci USA 89:9666-9670.

deMonasterio FM (1978) Center and surround mechanisms of opponent-color $\mathrm{X}$ and $\mathrm{Y}$ ganglion cells of macaque retina. J Neurophysiol 41:1418-1434.

DeVries SH, Baylor DA (1996) Correlated firing among different classes of ganglion cells in rabbit retina. Invest Ophthalmol Vis Sci 37:S688.

Dowling JE (1968) Synaptic organization of the frog retina: an electron microscopic analysis comparing the retinas of frogs and primates. Proc R Soc Lond [Biol] 170:205-228.

Dowling JE, Boycott BB (1966) Organization of the primate retina: electron microscopy. Proc R Soc Lond [Biol] 166:80-111.

Dubin MW (1970) The inner plexiform layer of the vertebrate retina: a quantitative and comparative electron microscopic analysis. J Comp Neurol 140:479-506.

Freed MA, Sterling P (1988) The ON-alpha ganglion cell of the cat retina and its presynaptic cell types. J Neurosci 8:2303-2320.

Freed MA, Pflug R, Kolb H, Nelson R (1996) ON-OFF amacrine cells in cat retina. J Comp Neurol 364:556-566.

Ghosh KK, Goodchild AK, Sefton AE and Martin PR (1996) Morphology of retinal ganglion cells in a New World monkey, the marmoset Callithrix jacchus. J Comp Neurol 366:76-92.

Goodchild AK, Ghosh KK, Martin PR (1996) Comparison of photoreceptor spatial density and ganglion cell morphology in the retina of human, macaque monkey, cat and the marmoset Callithrix jacchus. J Comp Neurol 366:55-75.

Gouras P (1967) The effects of light adaptation on rod and cone receptive fields organization of monkey retinal ganglion cells. J Physiol (Lond) 192:747-760.

Gouras P (1969) Antidromic responses of orthodromically-identified ganglion cells in monkey retina. J Physiol (Lond) 204:407-419.

Grünert U, Martin PR (1991) Rod bipolar cells in the macaque monkey retina: immunoreactivity and connectivity. J Neurosci 11:2742-2758.

Grünert U, Greferath U, Boycott BB, Wässle H (1993) Parasol (P alpha) ganglion cells of the primate fovea: immunocytochemical staining with antibodies against $\mathrm{GABA}_{\mathrm{A}}$ receptors. Vision Res 33:1-14.

Itoh K, Conley M, Diamond IT (1982) Retinal ganglion cell projections to individual layers of the lateral geniculate body in Galago crassicaudatus. J Comp Neurol 205:282-290.

Kaneda M, Hashimoto M, Kaneko A (1995) Neuronal nicotinic acetylcholine receptors of ganglion cells in the cat retina. Jpn J Physiol 45:491-508.

Kaplan E, Lee BB, Shapley RM (1990) New views of primate retinal function. Prog Retinal Res 9:273-336. 
Kier CK, Buchsbaum G, Sterling P (1995) How retinal microcircuits scale for ganglion cells of different size. J Neurosci 15:7673-7683.

Kolb H, Crooks J (1992) Neural circuitry of foveal ganglion cells in the human retina. Soc Neurosci Abstr 18:1029.

Kolb H, Dekorver L (1991) Midget ganglion cells of the parafovea of the human retina: a study by electron microscopy and serial section reconstructions. J Comp Neurol 303:617-636.

Kolb H, Nelson R (1985) Functional neurocircuitry of amacrine cells in the cat retina. In: Neurocircuitry of the retina, a Cajal memorial (Gallego A, Gouras P, eds), pp 215-232. Amsterdam: Elsevier.

Kolb H, Nelson R (1993) OFF-alpha and OFF-beta ganglion cells in cat retina. II. Neural circuit as revealed by electron microscopy of HRP stains. J Comp Neurol 329:85-110.

Kolb H, Nelson R, Mariani A (1981) Amacrine cells, bipolar cells and ganglion cells of the cat retina: a Golgi study. Vision Res 21:1081-1114.

Kolb H, Linberg KA, Fisher SK (1992) Neurons of the human retina: a Golgi study. J Comp Neurol 318:147-187.

Koontz MA, Hendrickson AE (1987) Stratified distribution of synapses in the inner plexiform layer of the primate retina. J Comp Neurol 263:581-592.

Koontz MA, Hendrickson AE (1990) Distribution of GABAimmunoreactive amacrine cell synapses in the inner plexiform layer of macaque monkey retina. Vis Neurosci 5:17-28.

Kouyama N, Marshak DW (1992) Bipolar cells specific for blue cones in the macaque retina. J Neurosci 12:1233-1252.

Krebs W, Krebs I (1989) Quantitative morphology of the central fovea in the primate retina. Am J Anat 184:225-236.

Leventhal AG, Rodieck RW, Dreher B (1981) Retinal ganglion cell classes in the Old World monkey: morphology and central projections. Science 213:1139-1142.

Marc RE, Liu W-LS, Muller JF (1988) Gap junctions in the inner plexiform layer of the goldfish retina. Vision Res 28:9-24.

Mariani AP (1990) Amacrine cells of the rhesus monkey retina. J Comp Neurol 301:382-400.

Mariani AP, Hersh LB (1988) Synaptic organization of cholinergic amacrine cells in the rhesus monkey retina. J Comp Neurol 267:269-280.

Marshak DW, Aldrich LB, DelValle J, Yamada T (1990) Localization of immunoreactive cholecystokinin precursor to amacrine cells and bipolar cells of the macaque monkey retina. J Neurosci 10:3045-3055.

Martin PR, Grünert U (1992) Spatial density and immunoreactivity of bipolar cells in the macaque monkey retina. J Comp Neurol 323:269-287.

Massey SC, Kittila CA, See TP (1996) ON alpha ganglion cells receive input from calbindin cone bipolar cells in rabbit retina. Invest Ophthalmol Vis Sci 37:S950.

Mastronarde DN (1983) Interactions between ganglion cells in cat retina. J Neurophysiol 49:350-365.

McMahon DG, Knapp AG, Dowling JE (1989) Horizontal cell gap junctions: single channel conductance and modulation by dopamine. Proc Natl Acad Sci USA 86:7639-7643.

Merigan WH, Maunsell JHR (1993) How parallel are the primate visual pathways? Annu Rev Neurosci 16:369-402.

Naito J (1989) Retinogeniculate projection fibers in the monkey optic nerve: a demonstration of the fiber pathways by retrograde axonal transport of WGA-HRP. J Comp Neurol 284:174-186.

Neuenschwander S, Singer W (1996) Long-range synchronization of oscillatory light responses in the cat retina and lateral geniculate nucleus. Nature 379:728-733.

O'Malley DM, Masland RH (1993) Responses of the starburst amacrine cells to moving stimuli. J Neurophysiol 69:730-738.

Peichl L (1991) Alpha ganglion cells in mammalian retinae: common properties, species differences, and some comments on other ganglion cells. Vis Neurosci 7:155-169.

Perry VH, Silveira LC (1988) Functional lamination in the ganglion cell layer of the macaque's retina. Neuroscience 25:217-223.

Perry VH, Oehler R, Cowey A (1984) Retinal ganglion cells that project to the dorsal lateral geniculate nucleus in the macaque monkey. Neuroscience 12:1125-1137.
Peters BN, Masland RH (1996) Responses to light of starburst amacrine cells. J Neurophysiol 75:469-480.

Peters A, Palay SL, Webster HF (1991) The fine structure of the nervous system. New York: Oxford UP.

Polyak SL (1941) The retina. Chicago: University of Chicago.

Raviola E, Raviola G (1982) Structure of the synaptic membranes in the inner plexiform layer of the retina: a freeze fracture study in monkeys and rabbits. J Comp Neurol 209:233-248.

Reale E, Luciano L, Spitznas M (1978) Communicating junctions of the human sensory retina. Albrecht Graefes Arch Klin Exp Ophthalmol 208:77-92.

Rodieck RW, Marshak DW (1992) Spatial density and distribution of choline acetyltransferase immunoreactive cells in human, macaque and baboon retinas. J Comp Neurol 321:46-64.

Rodieck RW, Binmoeller KR, Dineen J (1985) Parasol and midget ganglion cells of the human retina. J Comp Neurol 233:115-132.

Rodieck RW, Brening RK, Watanabe M (1993) The origin of parallel visual pathways. In: Proceedings of the Retina Research Foundation Symposia, Vol 5 (Shapley R, Lam DMK, eds), pp 117-144. Cambridge, MA: MIT.

Scobey RP (1981) Movement sensitivity of retinal ganglion cells in monkey. Vision Res 21:181-190.

Scobey RP, Horowitz JM (1976) Detection of image displacement by phasic cells in peripheral visual fields of the monkey. Vision Res $16: 15-24$.

Sterling P, Calkins DJ, Klug KJ, Schein Sj, Tsukamoto Y (1994) Parallel pathways from the primate fovea. Invest Ophthalmol Vis Sci 35:2001.

Tauchi M, Masland RH (1984) The shape and arrangement of the cholinergic neurons in the rabbit retina. Proc $R$ Soc Lond [Biol] 223:101-119.

Taylor WR, Wässle H (1995) Receptive field properties of starburst cholinergic amacrine cells in the rabbit retina. Eur $\mathrm{J}$ Neurosci 7:2308-2321.

Thier P, Bolz J (1985) Cholecystokinin in the cat retina: action of exogenous CCK8 and localization of cholecystokinin-like immunoreactivity. Invest Ophthalmol Vis Sci 26:266-272.

Vaney DI (1991) Many diverse types of retinal neurons show tracer coupling when injected with Biocytin or Neurobiotin. Neurosci Lett 125:187-190.

Vaney DI (1994) Patterns of neuronal coupling in the retina. Prog Retinal Eye Res 13:301-355.

Vaney DI, Peichl L, Boycott BB (1988) Neurofibrillar long-range amacrine cells in mammalian retinae. Proc $\mathrm{R}$ Soc Lond [Biol] 235:207-219.

Vardi N, Masarachia P, Sterling P (1989) Structure of the starburst amacrine network in the cat retina and its association with alpha ganglion cells. J Comp Neurol 288:601-611.

Wässle H, Grünert U, Chun M, Boycott BB (1995) The rod pathway of the macaque monkey retina: Identification of AII-amacrine cells with antibodies against calretinin. J Comp Neurol 361:537-551.

Watanabe M, Rodieck RW (1989) Parasol and midget ganglion cells of the primate retina. J Comp Neurol 289:434-454.

Watanabe M, Fukuda Y, Hsiao CF, Ito H (1985) Electron microscopic analysis of amacrine and bipolar cell inputs on Y-, X-, and $\mathrm{W}$ - cells in the cat retina. Brain Res 358:229-240.

Weber AJ, Stanford LR (1994) Synaptology of physiologically identified ganglion cells in the cat retina: a comparison of retinal $\mathrm{X}$ - and $\mathrm{Y}$-cells. J Comp Neurol 343:483-499.

Xin D, Bloomfield SA, Andrews AL (1995) The tracer coupling pattern of amacrine and ganglion cells in the rabbit retina. Invest Ophthalmol Vis Sci 36:S602.

Zhou ZJ, Marshak DW, Fain GL (1994) Amino acid receptors of midget and parasol ganglion cells in primate retina. Proc Natl Acad Sci USA 91:4907-4911. 